Board of Governors of the Federal Reserve System

International Finance Discussion Papers

Number 554

June 1996

\title{
REAL EXCHANGE RATES AND INFLATION IN EXCHANGE-RATE BASED STABILIZATIONS: AN EMPIRICAL EXAMINATION
}

Steven B. Kamin

NOTE: International Finance Discussion Papers are preliminary materials circulated to stimulate discussion and critical comment. References in publications to International Finance Discussion Papers (other than an acknowledgment that the writer has had access to unpublished material) should be cleared with the author or authors. 


\begin{abstract}
Considerable research has focused on explaining why currencies appreciate in real terms after the nominal exchange rate is stabilized, but this research generally has taken a theoretical approach, and rarely has tested its hypotheses empirically. In this paper I estimate a simple error-correction model for Mexico. based on the Salter-Swan framework, in which inflation is determined by (1) the gap between the actual real exchange rate and the exchange rate that clears the market for non-traded goods, and (2) persistence effects of past inflation. Using this model, I decompose the excess of Mexican inflation in 1988-94 over peso-adjusted international inflation rates--that is, the real appreciation of the peso--into that part attributable to the initial undervaluation of the peso, that part explained by the subsequent expansion of domestic demand, and that part attributable to inertial inflation. The results indicate that the effects of inertial inflation in appreciating the real exchange rate were quite temporary, lasting only about a year after the stabilization of the peso in 1988 . Of the real appreciation that took place between 1988 and 1994 , about half was attributable to the expansion of domestic demand--which appreciated the equilibrium real exchange rate in the non-tradeables sector--and about half reflected the correction of the initial undervaluation of the real exchange rate relative to its equilibrium level in the non-tradeables sector. Finally, the paper uses the model to illustrate the impact of various prospective exchange rate policies on inflation and the real exchange rate in Mexico.
\end{abstract}




\title{
Real Exchange Rates and Inflation in Exchange-Rate Based Stabilizations: An Empirical Examination
}

\author{
Steven B. Kamin
}

\section{Introduction}

In recent years, a substantial literature has developed to explain various trends associated with the use of fixed exchange rates to reduce high rates of inflation. These trends include an appreciation of the real exchange rate, strong growth of output and aggregate demand, and a widening of trade and current account deficits. Two broad approaches to explaining these developments have emerged. One approach focuses on explaining the stylized facts of exchange-rate based stabilizations in an equilibrium framework, assuming that prices clear the goods markets at each moment in time. (See Rebelo and Vegh, 1995, for an overview of equilibrium theories.) In this equilibrium approach, the disinflation associated with exchange-rate based stabilization is shown to raise aggregate demand, thereby boosting output, raising prices of non-tradeable goods, appreciating the real exchange rate (since prices of tradeables in domestic currency are fixed by the exchange rate), and widening the trade deficit.

The second broad approach toward understanding the effects of exchange-rate based stabilizations stresses the persistence of inflation in a framework in which goods and/or labor markets temporarily may be out of equilibrium. In what might be termed the "inertial inflation" approach, immediately following the implementation of a fixed exchange rate regime, inflation is posited to be slow to decline to international levels as a result of over-lapping contracts, imperfect credibility, or

\footnotetext{
${ }^{1}$ The author is a Senior Economist in the Division of International Finance, Board of Governors of the Federal Reserve System. I am grateful to David Bowman, Allan Brunner, Neil Ericsson, Jon Faust, David Gould, Dale Henderson, David Howard, Karen Johnson, Graciela Kaminsky, Andrew Levin, Bill Maloney, John Rogers, Ted Truman, Martin Uribe, and members of the IF Workshop for helpful comments and suggestions. Sudha Velugubanti provided excellent research assistance. This paper represents the views of the author and should not be interpreted as reflecting those of the Board of Governors of the Federal Reserve System or other members of its staff.
} 
backward-looking expectations. (See Edwards, 1993, Calvo and Vegh, 1994, and Dornbusch and Werner, 1994.) The presence of inertial inflation explains both the real appreciation of the exchange rate and the deterioration of trade performance observed during exchange-rate based stabilization programs, although it does not explain the frequently observed boom in output and demand following stabilization.

Notably, there have been few attempts to test directly either of the basic hypotheses outlined above. Within the equilibrium approach, there have been various efforts to develop numerical simulation models, and to compare the predictions of these models against actual trends in economies undergoing exchange rate based stabilization. (See Reinhart and Vegh, 1995, Rebelo and Vegh, 1995. Mendoza and Uribe. 1996, and Erceg and Levin, 1996.) However, such efforts are at best highly indirect tests of the equilibrium hypothesis, insofar as they rely on calibrated parameters and attempt only to match broad features of model simulations with the predictions of particular theories. Conversely, Dornbusch and Werner (1994) use an estimated model of Mexican inflation to show that fixing the exchange rate when inflation is high will generate significant real exchange rate appreciation because inflation is slow to adjust, but they do not test this hypothesis against the alternative hypothesis that an appreciation of the real equilibrium exchange rate is responsible for the slowness of inflation to decline to international levels.

In this paper. I develop an empirical model of Mexican inflation that incorporates both equilibrium and inertial factors, and use this model to gauge the relative contribution of these factors to the excess of Mexican inflation over foreign inflation rates--or equivalently, to the real appreciation of the Mexican peso--that occurred after the implementation of its exchange-rate based stabilization program in 1988. The model, based on the tradeable/non-tradeable goods framework pioneered by Salter (1959) and Swan (1960), posits that for a given level of aggregate demand, oniy one value of the real exchange rate--the ratio of tradeable to non-tradeable prices--will clear the market for non- 
tradeable goods. Even though this market-clearing real exchange rate is not the rate that necessarily is consistent with sustainable external balance, in this paper $\bar{I}$ refer to it as the "real equilibrium rate", since it is the rate toward which the actual real exchange rate will move in the short and medium term. Deviations of the real exchange rate from its "equilibrium" or market-clearing level lead to excess supplies or demands for non-tradeables, which in turn trigger equilibrating movements in nontradeables prices that return the real exchange rate to its equilibrium level.

Hence, inflation is explained, in the first instance, by the gap between the actual and equilibrium real exchange rate, or, since the level of the equilibrium real exchange rate depends upon the level of aggregate demand, by the relative levels of the actual real exchange rate and aggregate demand. The model is extended to incorporate the possible effects of inertial factors through the addition of lagged rates of inflation as explanatory variables.

The model is used to gauge the impact of changes in aggregate demand on the equilibrium real exchange rate, and hence on both non-tradeables inflation and on the actual real exchange rate, following implementation of an exchange-rate based stabilization program. Additionally, by analyzing the effects of lagged inflation on current inflation in the model, the separate contribution of inflation inertia to inflation and real exchange rate movements can be determined. Finally, the framework points to a third possible explanation for real appreciation during exchange-rate based stabilizations that has not been highlighted thus far in the literature. Prior to stabilization, adverse balance-ofpayments pressures are likely to cause the real exchange rate to be highly depreciated relative to the level required to induce equilibrium in the non-tradeables market. Therefore, once the nominal exchange rate is stabilized, non-tradeables prices may rise not as a result of an appreciation of the equilibrium real exchange rate, nor as a result of inertial factors, but rather in response to excess demands stemming from a pre-existing gap between the actual and equilibrium real exchange rate. Hence, at least some of the real appreciation observed during stabilization programs may represent 
merely an adjustment back to the pre-existing equilibrium level of the real exchange rate.

The plan of the paper is as follows. In Section II, I describe in greater detail the various theories of real appreciation during exchange-rate based stabilization programs, using the tradeables/non-tradeables approach as a framework for analysis. Section III describes the data used in the empirical analysis and the estimation of the model of Mexican inflation. In Section IV, the model is used to decompose the real appreciation of the Mexican peso from 1988 to 1994 into the three contributing factors discussed above: an appreciation of the real equilibrium exchange rate, inertial inflation, and adjustment to the pre-existing equilibrium level of the exchange rate. In Section V, I use the model to compare the likely impact on inflation of different future strategies for exchange rate management. Section VI concludes.

\section{Il. Explanations for Real Appreciation during Exchange-Rate Based Stabilizations}

Almost all "equilibrium" theories of real exchange rate appreciation, no matter how sophisticated the model underlying the theory, can be understood in terms of the relative supplies and demands for traded and non-traded goods. I first describe the simplest model of tradeables and nontradeables, and then review various theories of real exchange rate appreciation in light of that model.

\subsection{The Salter-Swan Model}

I follow Dornbusch (1980) in laying out the essential characteristics of the model of expenditure-switching and expenditure-reduction pioneered by Salter (1959) and Swan (1960). A small, open economy produces two goods, a traded good $(T)$ and a non-traded good $(N)$. The price of the traded good $\mathrm{P}_{\mathrm{T}}$ is determined by the level of the exchange rate $\mathrm{E}$ (local currency per dollar) and of foreign tradeables prices $\mathrm{P}_{\mathrm{T}}{ }^{*}$. The price of the non-tradeable $\mathrm{P}_{\mathrm{N}}$ is determined by equilibrium in the market fớ noñ-t̂radeabies. Producers in each sector maximize profits subject to declining margina! products of labor, the only variable input: 


$$
\begin{aligned}
& \operatorname{Max} \quad P_{i} Q_{i}-W L_{i} \\
& \text { s.t. } Q_{i}=Q_{i}\left(L_{i}\right) \quad Q_{i}^{\prime}(\quad)>0, Q_{i}^{\prime \prime}(\quad)<0 \\
& i=N, T \quad W=\text { wage rate }
\end{aligned}
$$

Profit maximization leads to implicit functions for labor demands as a function of real product wages in each sector:

$$
L_{T}=L_{i}\left(W \mid P_{i}\right) \quad L_{i}^{\prime}(\quad)<0
$$

Conditional on the prices of traded and non-traded goods, the wage rate $\mathrm{W}$ is determined so as to equate the sum of labor demands in the two sectors to the fixed, total labor supply:

$$
L_{T}\left(W \mid P_{T}\right)+L_{N}\left(W \mid P_{N}\right)=\underline{L}
$$

Log-differentiating, log-changes (denoted by ${ }^{\wedge}$ ) in equilibrium wages $W$ can be expressed as a function of changes in non-tradeables prices $\mathrm{P}_{\mathrm{N}}$ and tradeable prices $\mathrm{P}_{\mathrm{T}}{ }^{2}$ :

$$
\hat{W}=\gamma \hat{P}_{T}+(1-\gamma) \hat{P}_{N}
$$

Based on (4), changes in real wages in the two sectors can be expressed in terms of changes in relative prices:

$$
\begin{aligned}
& \hat{W}-\hat{P}_{T}=(1-\gamma)\left(\hat{P}_{N}-\hat{P}_{T}\right) \\
& \hat{W}-\hat{P}_{N}=\gamma\left(\hat{P}_{T}-\hat{P}_{N}\right)
\end{aligned}
$$

Based on (1), (2), and (5), one can write functions for the supplies of traded and non-traded goods in terms of relative prices, or equivalently, the real exchange rate, $\mathrm{P}_{\mathrm{T}} / \mathrm{P}_{\mathrm{N}}$ :

${ }^{2} \gamma$ represents the elasticity of demand for labor multiplied by the share of labor employed in the tradeables sector. 


$$
\begin{array}{ll}
S^{T}=S^{T}\left(P_{T} / P_{N}\right), & S^{T^{\prime}}(\quad)>0 \\
S^{N}=S^{N}\left(P_{T} / P_{N}\right), & S^{N^{\prime}}(\quad)<0
\end{array}
$$

I now turn to the demand for tradeable and non-tradeable goods, which are assumed to be determined by relative prices and total domestic demand or absorption A. Sectoral demands are decreasing in the relative price of that sector's good, and increasing in the level of total demand:

$$
\begin{array}{ll}
D^{T}=D^{T}\left(P_{T} P_{N}, A\right) & \partial D^{T} / \partial\left(P_{T} P_{N}\right)<0, \partial D^{T / \partial A}>0 \\
D^{N}=D^{N}\left(P_{T} / P_{N}, A\right) & \partial D^{N} / \partial\left(P_{T} / P_{N}\right)>0, \partial D^{N} / \partial A>0
\end{array}
$$

Based on equations (6) and (7), we can solve for equilibrium in the markets for traded and nontradeable goods. The NN curve in Figure 1 below traces out the combinations of the real exchange rate and absorption that lead to equilibrium in the market for non-tradeables: increases in absorption lead to excess demands for non-tradeables that can only be moderated through increases in the relative price of non-tradeables, that is, an appreciation of the real exchange rate. ${ }^{3}$

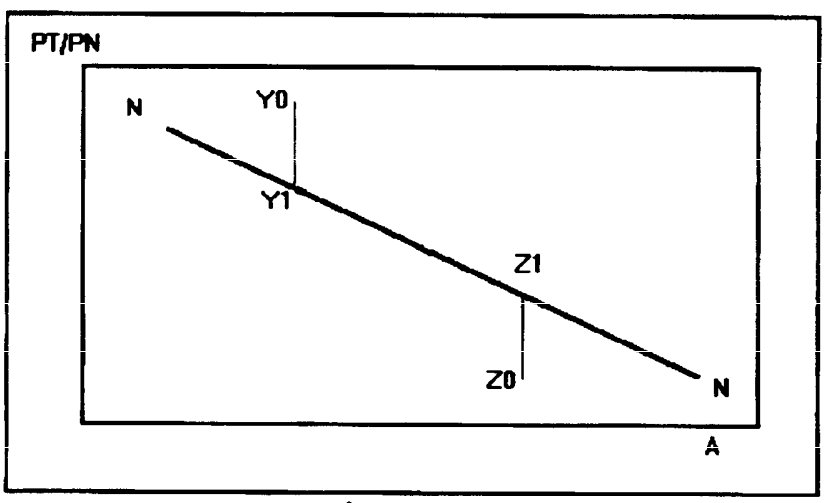

Pigure 1

${ }^{3}$ See Perez-Lopez Elguezabal (1995) for derivation of similar theoretical resuits based on a model with a domestically produced good and a good that is only imported. This model is used as the basis for a cointegration analysis of Mexican real exchange rates and industrial production similar to that conducted in this paper. 
I assume that non-tradeables prices do not move instantly to equate supplies and demands for non-tradeables. Therefore, the economy may be off the NN curve temporarily. However, the adjustment of non-tradeables prices to excess supplies or demands for non-tradeables will move the economy back to the NN curve over time. As shown in Figure 1, point Y0 represents a point of excess demand for non-tradeables, with the real exchange rate being more depreciated than its equilibrium value in the non-tradeables market, given the level of absorption. At this point, for a given nominal exchange rate $E$, we would expect demand pressures to raise non-tradeables prices $P_{N}$ until the real exchange rate $\mathrm{P}_{T} / \mathrm{P}_{\mathrm{N}}$ appreciated sufficiently to move the economy to point $\mathrm{Y} 1$.

Conversely, if the real exchange rate is excessively appreciated, as in point $\mathrm{Z} 0$, we would expect a reduction in non-tradeables prices to cause non-tradeables defiation to restore equilibrium at $\mathrm{Zl}$.

In Figure 2, I complete the conventional "Salter-Swan" diagram by adding the TT curve, which represents combinations of the real exchange rate and absorption for which the demand for tradeables equal their supply--that is, which lead to a balanced trade account. Increases in absortion lead to increased demand for tradeables, and hence a trade deficit, that requires a depreciation of the real exchange rate to correct (if trade balance is to be maintained). The TT curve is shown with a lighter line than the NN curve to indicate that the forces moving the economy toward the TT curve, when it is off that curve, are much weaker than the forces moving the economy toward the NN curve. This is likely to be true for two reasons. First, excess demands or supplies of tradeable goods--which result when the economy is off the TT curve--lead in the first instance only to trade deficits or surpluses, respectively; imbalances in the tradeables market do not affect the

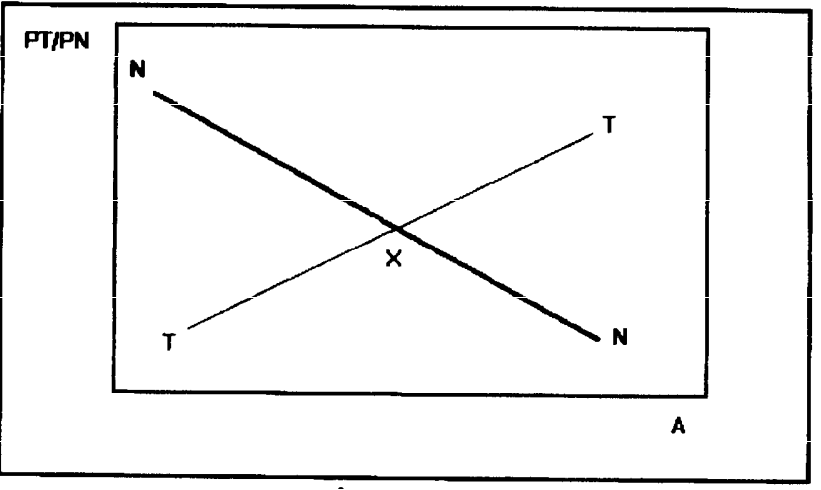

Fìgure 2 price of non-tradeable goods, and they do not directly affect the price of tradeables either, since those 
prices are fixed by the exchange rate and the price of foreign tradeables. Second, trade imbalances may be associated with excess demands or supplies of foreign exchange, which may induce adjustments of the nominal exchange rate that in turn move the real exchange rate in the direction of the TT curve. However, depending upon the extent to which trade imbalances are financed by capital flows, and depending upon the exchange rate regime being implemented by the authorities, such adjustments may be extremely slow in the short and medium term.

In sum, in the presence of substantial net capital flows, the Salter-Swan framework points to much stronger forces moving the real exchange rate toward equilibrium along the NN curve than along the TT curve. For this reason, in this paper I will refer to the value of the real exchange rate that clears the non-tradeable goods market as the "equilibrium real exchange rate". In this regard, my definition differs from the more conventional definition of the real equilibrium rate as the rate that induces current account (or current account plus sustainable net capital flows) balance at some "normal" level of output--point $X$ in Figure 2 above, corresponding to equilibrium in both the nontradeables and tradeables markets, might fit that conventional definition. ${ }^{4}$ While that definition highlights the level of the real exchange rate that is sustainable in the long run, it is the nontradeables-market-clearing exchange rate that is more likely to guide movements of the actual real exchange rate in the short and medium term.

\section{II.2 Explanations for Real Appreciation During Exchange-Rate Based Stabilizations}

Chart 1 indicates the paths of the multilateral real exchange rate, a reasonable proxy for the

${ }^{4}$ Warner (1996) focuses on the more conventional definition of the equilibrium real exchange rate in his attempt to explain the real appreciation of the Mexican peso during the late 1980s. In contrast to our study, which focuses on the dynamics of adjustment to equilibrium in the non-traded goods sector. Warner solves a more sophisticated version of the Salter-Swan model described above for the real exchange rate that generates equilibrium in both the traded and non-traded goods sectors-that is, the point where the NN and TT curves cross. In his empirical work, he finds that Mexico's terms of trade and capital inflows best explain the real exchange rate, which is highly consistent with the premise of this paper--that the NN curve remains fixed while the TT curve, which is the one that is moved by the terms of trade and capital flows, shifts around. 
ratio of non-tradeables to tradeables prices, for Argentina and Mexico, two countries which adhered to their exchange-rate based stabilization programs for relatively long periods. The vertical lines mark the initiation of Mexico's program in January 1988 and the start of Argentina's period of exchange rate stability in March 1990 (which continues to this day). It is apparent that real exchange rate appreciation was an important feature of both exchange-rate based stabilization programs.

Explanations in the literature for this real appreciation, which has accompanied many other such programs as well, can be divided into "equilibrium" and "inertial" theories.

Equilibrium theories. In equilibrium theories, the market for non-tradeables remains in equilibrium-demand equals supply--at all times. Real exchange rate appreciation is hypothesized to result from an expansion of overall domestic spending that increases the demand for both tradeables and nontradeables. Because non-tradeable prices rise in response while tradeables prices are fixed by the (fixed) nominal exchange rate and foreign prices, the relative price of tradeables falls. This is represented as a move down (and along) the NN curve from $\mathrm{X} 0$ to $\mathrm{X} 1$ in Figure 3, associated with an increase in aggregate demand from A0 to $A 1$; it is assumed that increased capital inflows accomodate the resultant widening of the

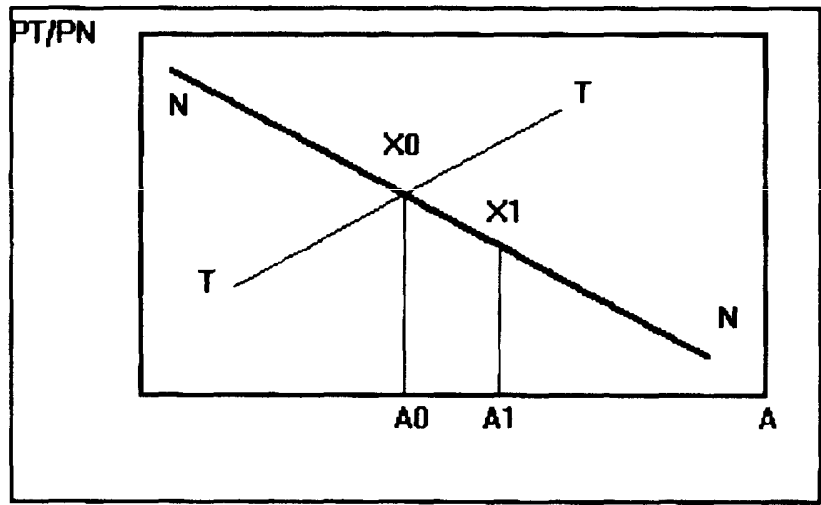

Figure 3 trade deficit. These features all are consistent with trends observed in actual stabilization programs. (Kiguel and Liviatan, 1992, and Vegh, 1992.)

Different theories point to different causes of the increased expenditures associated with

${ }^{5}$ Conventionally, the beginning of Argentina's program is dated from the start of the Convertibility Program in April 1991. However, Argentina's (floating) nominal exchange rate stabilized abruptly in March 1990 and remained stable until close to the end of 1990, when it depreciated sharply before stabilizing again. In addition, monthly inflation fell from nearly 100 percent in March 1990 to only about 11 percent in the following month. 
stabilization programs. Calvo and Vegh (1993) focus on the possibility that the stabilization is not credible, so that agents expect interest rates--and hence the effective price of consumption--to be lower at the onset of the program than in the future, when the program might fail; this generates an increased demand for both tradeables and non-tradeables that appreciates the real exchange rate. In Uribe (1995), Roldos (1995), and Úribe and Mendoza (1996), inflation acts as a tax on investment and on money balances; reductions in inflation associated with exchange-rate based stabilization programs lower this tax, thereby leading to increased investment and consumption, and, at least initially, to higher non-tradeables prices and an appreciated real exchange rate. Rebelo (1994) generates similar effects when focusing on fiscal, rather than exchange-rate based, stabilizations: restoration of fisca! sustainability, by reducing the need for future distortionary finance, reduces deadweight losses, increases wealth, and thereby generates increases in expenditures that raise the relative price of nontradeables.

Some equilibrium explanations of the real appreciation of the exchange rate also point to possible downwards movements of the $\mathrm{NN}$ curve itself. It is widely believed (the Balassa-Samuelson effect) that higher productivity growth in the tradeable than the non-tradeable sector will generate increases in the relative price of non-tradeables. If relative productivity in the tradeables sector tended to increase after stabilizations, this could explain the movement of the real exchange rate.

A downward shift in the NN curve could also reflect the differential effect of the stabilization on the demand for goods in the two sectors. Erceg and Levine (1996) argue that the stabilization of infiation, by improving the return on investments, generates a sharp increase in the desired capital stock. Since much of this additional stock consists of infrastructure and buildings, additional spending fal!s heaviest on construction, a non-tradeable good, and thereby would raise the relative price of nontradeables, even if overal! domestic spending remained unchanged.

Inertial theories. In inertial theories, real exchange rate appreciation represents a movement away from 
equilibrium in the non-traded goods sector. It is assumed that the economy starts out in a highinflation equilibrium, as shown in Figure 4 at $\mathrm{X0}$, with wages, non-tradeable prices, and the foreign currency value of the dollar (times foreign prices) all growing at the same rate. Rodriguez (1982) posits that non-tradeables inflation depends upon expected inflation--which adjusts only gradually to changes in actual inflation--and excess demand for non-tradeables. In Dornbusch and Werner (1994), inflation depends upon wage growth, which is equal to lagged inflation (a proxy for expectations) plus an adjustment for the ratio of output to potential output; Edwards (1993) assumes that wage growth also depends upon the credibility of the

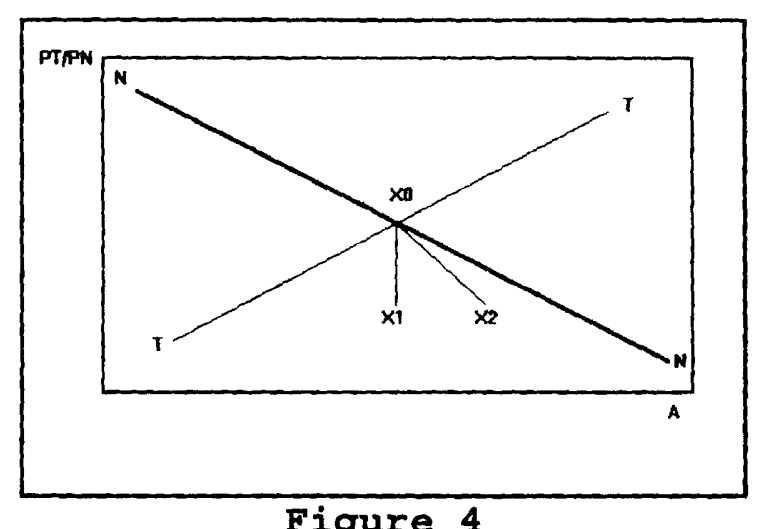

Figure 4 stabilization program itself. Once a stabilization program is initiated and the exchange rate is fixed, wage growth and hence non-tradeable price growth necessarily continue for a certain length of time before damping down, thereby leading to real appreciation of the exchange rate. This is shown as the movement from point $\mathrm{X} 0$ to point $\mathrm{X} 1$.

Critics of inertia stories point out that inertial inflation will lead to a contraction in the demand for non-traded goods--which is consistent with the placement of point X1 in the excess-supply-ofnontradeables quadrant--whereas a stylized fact of exchange-rate based stabilizations is a boom in spending, especially in the non-tradeables sector, in its early phases. (See Calvo and Mendoza, 1996, Erceg and Levin, 1996.) However, there is nothing in the inertial inflation story that precludes an expansion of overall domestic spending, alongside the propagation of inertial inflation, for any or all 
of the reasons outlined earlier. ${ }^{\circ}$ Were inertial inflation to be combined with growing demand, as indicated in Figure 4 by a move from point $\mathrm{X} 0$ to point $\mathrm{X} 2$, one would observe both an expansion of economic activity and a real exchange rate appreciation attributable. at least in part, to inertial forces. '

\section{II.3 The Adjustment-to-Equilibrium Hypothesis}

Both the equilibrium and inertial theories described above assume that at the time the exchange-rate based stabilization program is initiated, the economy starts out in equilibrium, that is, the real exchange rate is on the $\mathrm{NN}$ curve. Yet, as shown on Chart 1, a striking feature of the Argentine and Mexican stabilization programs is not only that the real exchange rate appreciated after they were initiated, but that the real exchange rate started out at a relatively depreciated level.

This probably was no accident. In both countries, high inflation was associated with financial instability and external debt problems which encouraged net capital outflows and a deterioration of the balance of payments. Such balance-of-payments pressures required sharp depreciations of the real exchange rate that might have caused it to be, at least temporarily, more depreciated than its nontradeable sector-clearing level. This is shown in Figure 5, where the T'T curve represents the locus of points where the current account ${ }^{8}$ plus the capital account KA are in balance:

$$
D^{T}\left(P_{T} / P_{N}\right)=S^{T}\left(P_{T} / P_{N}\right)+K A
$$

When the economy has ready access to international capital markets, the capital account may

${ }^{6}$ In Rodriguez (1982), the slow-to-adjust inflation expectations are themselves potentially expansionary, since actual interest rates--which are tied to the exogenous rate of exchange rate depreciation and to foreign interest rates--fall more quickly than expected inflation rates after a stabilization program is implemented, thereby lowering the ex ante real interest rate and raising aggregate demand.

${ }^{7}$ Dornbusch and Werner (1994) justify the applicability of their model to Mexico by noting that by 1993, output growth was slowing and employment was falling. consistent with what they term the "overvaluation hypothesis"

${ }^{8} \mathrm{We}$ implicitly equate the trade balance with the current account balance, abstracting from factor payments such as interest payments or wage remittances. 
accomodate the trade account. so that the $T^{\prime} T^{\prime}$ curve shifts endogenously to cover trade deficits. If the economy loses access to international capital markets, however, the T'T' curve may become binding.

In Figure 5, the T'T' curve is drawn for a negative capital account, such as in the case of the capital outflows from some developing countries during the 1980s, so that external balance requires a trade surplus. Governments in this situation may choose to locate their economy at a point such as X0, where the real exchange rate is depreciated relative to its equilibrium value on the $\mathrm{NN}$ curve, rather than at $\mathrm{Xl}$, where the nontradeable sector is in equilibrium but at a much lower level of absorption A. Hówever, because $\mathrm{X} 0$ is a point of excess demand for nontradeables, keeping the economy at that point is

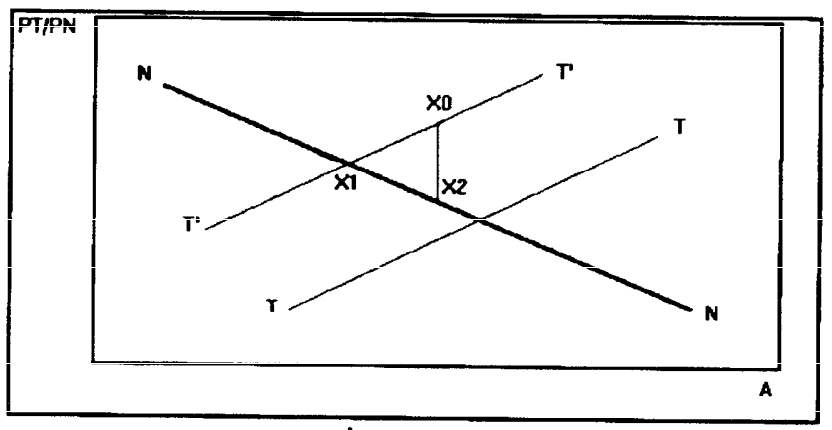

Figure 5

likely to generate high levels of inflation, as indeed was experienced by the countries most vulnerable to the debt crisis of the $1980 \mathrm{~s}$.

Now assume that the economy is at $\mathrm{X} 0$ and an exchange-rate based disinflation program is initiated. Once the exchange rate is fixed, inflationary pressures associated with the excessively depreciated real exchange rate will drive the relative price of tradeables downward until, at an unchanged level of absorption, the economy reaches equilibrium at X2. ${ }^{9}$ Hence, the real appreciation that follows exchange-rate based stabilization may be due to neither a change in the equilibrium real exchange rate nor to inertial factors, but rather to an adjustment toward an unchanged equilibrium

${ }^{9}$ Gil-Diaz and Carstens (1995) seem implicitly to rely upon a variant of this adjustment-toequilibrium argument to justify the real appreciation of the peso that occurred after the 1988 stabilization program was implemented. They present a calibrated model of Mexican prices in which changes in the nominal exchange rate lead to equi-proportionate increases in the level of the CPI over time. The model roughly reproduces the actual increase in the CPI during 1988-94, suggesting that price inflation during that period reflected a catch-up of prices to the excessively depreciated level of the exchange rate in the pre-1988 period. 
point.

\section{An Empirical Model of Inflation and Real Exchange Rate Appreciation}

In this section, I develop an empirical model which links Mexican price inflation to the gap between the actual and the equilibrium real exchange rate. In the following section, I use this model to gauge the relative contribution of the factors described above--equilibrium real exchange rate changes, inertial infiation, and adjustment to equilibrium--to the real appreciation of the Mexican peso after the 1988 stabilization program was put in place.

III.1 Estimation Strategy

Equation (9) below represents the simplest formulation of the NN curve for equilibrium in the non-tradeables market. The real exchange rate RER is the ratio of tradeables to non-tradeables prices $P_{T} / P_{N}$; the equilibrium real exchange rate $R E R^{*}$ is a declining function of absorption $A$ :

$$
R E R^{*}=\alpha_{0}-\alpha_{1} A, \quad \alpha_{1}>0
$$

If, as suggested in 11.3 above, the real exchange rate remains persistently more depreciated than its non-tradeables equilibrium value, equation (9) cannot be estimated directily in order to identify the parameters of the NN curve. However, even in the face of persistent disequilibria in the nontradeables market, one would expect the rate of change of non-tradeables prices to remain systematically related to the gap between actual and equilibrium exchange rates. This relationship can be used to identify indirectly the parameters of equation (9). Toward that end, equation (10) depicts a partial adjustment process in which changes in non-tradeables prices are proportional to the gap between the equilibrium and actual real exchange rates:

$$
\Delta P_{N}=\beta\left(R E R_{-1}=R E R_{-1}^{*}\right), \quad \beta>0
$$

Substituting Equation (9) for RER* in Equation (10): 


$$
\Delta P_{N}=-\beta \alpha_{0}+\beta R E R_{-1}+\beta \alpha_{1} A_{-1}
$$

Equation (11) assumes that non-tradeables prices move uniformly over time to close the gap between the actual and the equilibrium exchange rate. In practice, however, shocks to exchange rates, foreign prices, or domestic prices may have impact effects upon non-tradeables prices that differ from their effects working solely through the partial adjustment process. Additionally, as discussed above, current inflation rates may be linked to past inflation rates through the various "inertial" processes described in II.2. To take into account these additional factors in inflation determination, I estimate an equation based on (12) below:

$$
\Delta P_{N}=-\beta \alpha_{0}+\beta R E R_{-1}+\beta \alpha_{1} A_{-1}+\sum_{n=1}^{12} \lambda_{n} \Delta P_{N_{-n}}+\sum_{n=0}^{12} \gamma_{n} \Delta E_{-n}+\sum_{n=0}^{12} \phi_{n} \Delta P_{T_{-n}}^{*}
$$

Equation (12) is an unrestricted error-correction model for deviations of the real exchange rate from a cointegrating vector, depicted in equation (9), between the real exchange rate and absorption. The lags of inflation and exchange rate depreciation represent the dynamic response terms that distinguish an error-correction model from its more restricted variant, the fractional adjustment model indicated in equation (11). They also play an important role in minimizing the probability of simultaneity bias. The Salter-Swan framework takes as predetermined the level of absorption and, if one allows for persistent nominal exchange rate changes that offset non-tradeables inflation, the level of the real exchange rate as well. However, changes in non-tradeables inflation are likely to feed back onto the real exchange rate and absorption. This means that if the error term in equation (11) is autocorrelated, the lagged real exchange rate and lagged absorption in equation (11) would be correlated with the error term, causing estimated coefficients to be biased. The addition of lagged inflation and exchange rate depreciation in equation (12), by providing a richer dynamic structure to explain the adjustment process of non-tradeables inflation, should reduce autocorrelations of the error 
term and hence minimize the risk of simultaneity bias.

Finally, it should be acknowledged that equation (12) does not include the traditional determinants of inflation: monetary and (perhaps to a lesser extent) fiscal policy. While monetary and fiscal policy may be fundamental causes of inflation, they are regarded as influencing inflation solely through their effects upon inflation's proximate determinants, the real exchange rate and absorption. In that sense, equation (12) represents a narrow description of the inflation process, since it focuses only upon the proximate causes of inflation. On the other hand, as will be seen below, even the narrow description of inflation represented by equation (12) will be adequate to address various interesting issues concerning the behavior of inflation and the real exchange rate in Mexico.

\section{2 Choice of Data}

Because monthly data are not available for all the variables specified in equation (12), we use proxies in certain cases:

\begin{tabular}{||l|l|}
\hline Theoretical Variable & Empirical Proxy \\
\hline Real exchange rate (RER) & $\begin{array}{l}\text { Real Mexico-US bilateral exchange rate } \\
\text { (RER=E * US CPI/Mexican CPI) }\end{array}$ \\
\hline Absorption (A) & Detrended level of industrial production (IP) \\
\hline Non-tradeable price $\left(\mathrm{P}_{\mathrm{N}}\right)$ & Seasonally-adjusted Mexican CPI (P) \\
\hline Nominal exchange rate $(\mathrm{E})$ & Mexico-US exchange rate, pesos per dollar (E) \\
\hline Foreign tradeable price $\left(\mathrm{P}_{\mathrm{T}}{ }^{*}\right)$ & US CPI $\left(\mathrm{P}^{*}\right)$ \\
\hline
\end{tabular}

The data used are well-correlated with the variables for which they are proxying, so our estimation is unlikely to be biased significantly by measurement error:

Real exchange rate Mexico-US bilateral trade accounts for upwards of 70 percent of total Mexican trade in recent years, so the use of a bilateral exchange rate instead of a multilateral rate is warranted in this instance. Additionally, the ratio of tradeabie prices to the Mexican CPI should move proportionally to the ratio of tradeables prices to Mexican non-tradeable prices. To see this, note that 
the Mexican CPI, denoted P, will be a weighted average of tradeable and non-tradeable prices:

$$
P=P_{N}^{\alpha} P_{T}^{1-\alpha}=P_{N}^{\alpha}\left(E P_{T}^{*}\right)^{(1-\alpha)}
$$

Therefore, substituting the Mexican CPI $(P)$ for non-tradeables prices $\left(\mathrm{P}_{N}\right)$ in the real exchange rate,

$$
\left(E P_{T}^{*}\right) / P=\left(E P_{T}^{*}\right) /\left(P_{N}^{\alpha}\left(E P_{T}^{*}\right)^{(1-\alpha)}\right)=\left(E P_{T}^{*}\right)^{\alpha} / P_{N}^{\alpha}=\left[\left(E P_{T}^{*}\right) / P_{N}\right]^{\alpha}
$$

To the extent that the U.S. CPI--P*-- represents a good proxy for the Mexican tradeables prices in dollars-- $\mathrm{P}_{\mathrm{T}}{ }^{*}-$-the $\mathrm{CPI}$-deflated bilateral exchange rate will be an exponential function of the ratio of tradeables to non-tradeables prices. ${ }^{10}$

Price inflation We use the rate of $\mathrm{CPI}$ inflation as a proxy for non-tradeables inflation. Based on Equation (13), CPI inflation can be written:

$$
\hat{P}=\alpha \hat{P}_{N}+(1-\alpha) \hat{E}+(1-\alpha) \hat{P}_{T}^{*}
$$

Since the growth rates of $\mathrm{E}$ and $\mathrm{P}_{\mathrm{T}}{ }^{*}$ will appear on the right-hand side of the estimated version of Equation (12), the remaining, unexplained variation in aggregate price inflation will be exactly the variation in non-tradeable price inflation.

Absorption Absorption is equal to real GDP minus the trade balance." Because monthly data on GDP or on the trade balance on a national income accounts basis are not available, we use data on industrial production instead. Chart 2 compares seasonally adjusted quarterly levels of real GDP and industrial production--they are relatively well correlated.

In the analysis thus far, including the derivation of the supply curves shown in equation (6), I

${ }^{10}$ The inflation model described in III.4 below was virtually unchanged when estimated with the US PPI rather than the US CPI. GDP - (X-M).

${ }^{11} \mathrm{GDP}=\mathrm{C}+\mathrm{I}+\mathrm{G}+(\mathrm{X}-\mathrm{M})$. Domestic spending or absorption $\mathrm{A}=\mathrm{C}+\mathrm{I}+\mathrm{G}=$ 
have assumed that productive capacity is constant, so that the impact of demand on non-tradeables prices can be summarized by the level of absorption A (along with the real exchange rate RER). In reality, however, productive capacity in the non-tradeable sector tends to grow over time, and it is the level of absorption in relation to productive capacity--not the level of absorption alone--that should have a systematic relationship with inflation and the real exchange rate. Hence, to estimate equation (12), I assume that productive capacity in the non-tradeables sector can be approximated by the loglinear trend in industrial production, and use the difference between the actual (log) level of industrial production and its trend as a proxy for absorption $\mathrm{A}$ in that equation. The top panel of Chart 3 compares the log of industrial production with its estimated linear time trend, while the bottom panel shows the difference between the two. The sustained periods in which output lies below trend in the 1980s and above trend in the early 1990s are consistent with the basic facts: recession and macroeconomic turmoil in $1 \overline{9} \overline{8} 2-\overline{8} \overline{7}$, followed by pronounced recovery in $1988-92$.

\section{III.3 Data Description and Time Series Properties}

\section{Graphical evidence}

Chart 4 plots the monthly growth rate (log change) of the seasonally-adjusted Mexican CPI against the rate of depreciation of the Mexico-US bilateral exchange rate. At least four distinct phases are evident: 1980-81, a period of moderate inflation; 1982-87, when inflation and depreciation surged in response to the debt crisis and related developments; 1988-94, when the exchange-rate based stabilization program reduced the inflation rate, albeit less quickly than the rate of depreciation; and 1995-present, when infiation rebounded after the devaluation and float of the peso in December 1994.

Chart 5 plots monthly $\mathrm{CPI}$ inflation against the log of the real bilateral exchange rate. Even without holding absorption constant, the two series are very well conrelated, providing prima facie support for the view, outlined in Section II, that inflation reflects an adjustment of prices to the deviation of the level of the real exchange rate from its equilibrium value. 
Chart 6 plots monthly CPI inflation against detrended industrial production. Theoretically, holding the real exchange rate constant, increases in the output gap (actual minus trend) should lead to higher inflation. However, the output gap and inflation are closer to being negatively correlated than positively correlated over the sample period. Chart 7, which plots the output gap against the reciprocal of the real exchange rate (that is, the real exchange value of the peso), explains this perverse result: the output gap and the real peso value of the dollar are very strongly correlated, so that reductions in output tend to be associated with real depreciations of the peso, which are inflationary. Stationarity

I first examine the order of integration of the data series used in our estimated equation. Table 1 presents the results of applying augmented Dickey-Fuller tests for unit roots to the data. There are some ambiguities in the test results. Looking at the tests for level stationarity (tests for rejection of I(1)), the logs of Mexican prices p, U.S. prices $p^{*}$, and the exchange rate e clearly are non-stationary. One cannot reject a unit root for the real exchange rate rer, either, but at 0.95 , the root is more clearly distinct from unity, and at 2.58, the Dickey-Fuller statistic is not far below the critical value of 2.88 . Hence, some marginal evidence that the real exchange rate is stationary exists. Similarly, a unit root in detrended industrial production ip $^{12}$ cannot be rejected at the 5 percent level, but the Dickey-Fuller statistic of 3.04 is close to its critical value of 3.44 , and its root of .92 also is well below unity.

Turning to the evidence for difference stationarity (rejection of I(2)), the differences of the nominal exchange rate, U.S. prices, the real exchange rate, and detrended IP clearly have roots less than unity. The evidence for the log differences in the Mexican CPI--that is, the inflation rate--is more ambiguous. While a unit root cannot be rejected, its value of 0.91 is moderately below unity, and the Dickey-Fuller statistic of 2.5 is reasonably close to its 5 percent critical value as well. Moreover,

\footnotetext{
${ }^{12}$ As described in a footnote to Table 1 , the Dickey-Fuller test was actually applied to the nondetrended $\log$ of industrial production, and a time trend was added to the regression equation.
} 
when we examine the test to see if $\mathrm{I}(3)$ can be rejected for Mexican prices, we observe a root of -.17 , which is so far from a positive value of unity as to further suggest that the first difference of prices may be marginally stationary.

\section{Cointegration}

Table 2 presents the results from the application of the Johansen test to the log levels of Mexican prices $p$, US prices $\mathrm{p}^{*}$, the nominal exchange rate e, and detrended industrial production ip. ${ }^{13}$ The maximal eigenvalue and trace eigenvalue tests appear to reject the nuil hypothesis that the variables are not cointegrated in favor of at least one cointegrating relationship. The bottom panel reports the standardized eigenvectors associated with the eigenvalues shown in the top panel; the first row is the estimated cointegrating vector associated with the most significant eigenvalue, which can be re-written:

$$
p=.94 e+1.76 p^{*}+2.97 i p
$$

As expected, a depreciation of the nominal exchange rate (increase in e) leads to an increase in prices $\mathrm{p}$ of roughly the same proportion. Increases in foreign prices $\mathrm{p}^{*}$ also increase $\mathrm{p}$, although the coefficient of 1.76 is higher than the expected unitary value of that parameter. Finally, increases in detrended industrial production ip also lead to higher price levels.

The top panel of Table 2 also presents moderate evidence of a second cointegrating vector; the second largest eigenvalue is of the same order of magnitude as the largest eigenvalue, the maximal eigenvalue statistics are not far below their $95 \%$ critical values, and the trace eigenvalue statistics reject the null hypothesis of zero or one cointegrating vector in favor of at least two cointegrating vectors. If there are two cointegrating vectors, the most obvious possibility is that they are comprised of (1) $p, p^{*}$, and $e--$ that is, the real exchange rate--and (2) ip by itself. This possibility is suggested by

\footnotetext{
${ }^{13}$ Cointegration analyses also were performed using non-detrended industrial production and a separate time trend. These analyses produced somewhat different estimates of the cointegrating vectors, but very similar results regarding the number of cointegrating vectors.
} 
the fact that detrended industrial production and the real exchange rate were shown to be nearly stationary by the augmented Dickey-Fuller tests described above.

To test this hypothesis, the Johansen test is applied to $\mathrm{p}, \mathrm{p}^{*}$, and e alone. As shown in Table 3 , the results, while ambiguous, provide qualified support for the existence of at least one cointegrating vector among the three variables. The trace eigenvalue statistics allow us to reject the null hypothesis of no cointegrating vectors at the 5 percent level, while the maximal eigenvalues are not very far below their critical values.

Finally. I apply the Johansen procedure to a two-variable system of detrended industrial production ip and the real exchange rate rer $=\mathrm{e}+\mathrm{p}^{*}-\mathrm{p}$. The test statistics shown in the top panel of Table 4 indicate unambiguously that the null hypothesis of zero cointegrating vectors can be rejected. ${ }^{14}$ The results also indicate that the null of 1 or fewer cointegrating vectors can be rejected; with only two variables in the system, this means that each must comprise its own cointegrating vector, that is, that each is stationary. However, the small size of the second eigenvalue suggests that this result should not be relied upon too heavily.

The existence of a cointegrating vector among $p, p^{*}, e$, and ip further suggests that Mexican inflation--the log-change in Mexican prices--is stationary. Log-changes of the nominal exchange rate, U.S. prices, and industrial production are stationary, and for those variables plus Mexican prices to form a cointegrating vector, all four variables must be of the same order of integration.

\section{III.4 Estimation of the Inflation Equation}

The unit root and cointegration tests described above suggest that it may not be inappropriate

\footnotetext{
${ }^{14}$ Perez-Lopez Elguezabal (1995) analyzed the cointegration properties of the log Mexican-US real bilateral exchange rate and log non-detrended industrial production using the Engle-Granger approach. Regressing industrial production on the real exchange rate, he found that the depreciation of the real exchange rate significantly depressed industrial production. The residuals from the regression were found to be stationary, indicating that the two series are cointegrated. Hence, his results were essentially consistent with those in this paper.
} 
to model the Mexican inflation rate as a function of the level of the real exchange rate and output gap, as well as lagged changes in Mexican inflation, exchange rate depreciation, and U.S. inflation. To estimate a single-equation model of Mexican inflation. I start out with a highly unrestricted model, essentially similar to equation (12) above, but with variables expressed in logs rather than levels:

$$
\Delta p=\alpha+\beta r e r_{-1}+\delta i p_{-1}+\sum_{n=1}^{12} \lambda_{n} \Delta p_{-\pi}+\sum_{n=0}^{12} \gamma_{n} \Delta e_{-n}+\sum_{n=0}^{12} \phi_{n} \Delta p_{-\pi}^{*}+u
$$

The equation was estimated over the sample, $1980.2-1995.12$. The lags in the equation were then progressively removed, based on standard general-to-specific methodology, if their t-statistics were substantially less than 2 .

The estimation results are indicated in Table 5. The OLS results are presented in the first column. To ascertain the robustness of the equation, it was also estimated using non-seasonally adjusted data for the Mexican CPI, along with seasonal dummies (not shown); the results are virtually identical with the OLS equation for most coefficients. Additionally, instrumental variables estimation was used to correct for possible simultaneity problems associated with the contemporaneous change in the nominal exchange rate $\Delta \mathrm{e}$. Notably, under IV estimation, the coefficient on $\Delta \mathrm{e}$ declines in both magnitude and statistical significance, but most of the other coefficients in the model are unchanged. Hence, we focus on the basic OLS equation in the remainder of the paper.

Various aspects of the results are worth pointing out. First, the error-correction feature of Mexican infiation clearly is confirmed by the data, as evidenced by the statistical significance of the coefficients on lagged rer and ip. Second, dynamic factors also are important in explaining Mexican inflation in the short run. The sum of the coefficients on lags of the dependent variable is .68 , indicating that inflation shows a moderate degree of persistence. Changes in the nominal exchange rate also exert a statistically significant effect on inflation, although the coefficient is relatively small. 
The estimated equation shows evidence of heteroscedastic errors, as indicated by the significant $\mathrm{ARCH}$ and $\mathrm{Xi}^{2}$ statistics, as well as the plot of the equation residuals in Chart 8 . Table 5 therefore presents heteroscedasticity-corrected t-statistics in brackets for the basic OLS equation. Based on these statistics, some lagged dynamic variables become insignificant, but the coefficients on the lagged levels and on the first lags of changes in exchange rates and prices remain significant.

The estimated equation also shows signs of parameter instability over the sample. Chart 9 indicates the coefficient estimates resulting from recursive estimation of the equation when the data range is extended progressively from 1981.12 through 1995.12 . Chart 10 presents the Chow test statistic for model stability as the sample size is adjusted progressively through time (the so-called "Nstep down" Chow test). Not surprisingly, structural breaks (indicated when the scaled Chow statistic exceeds unity) are identified in 1982 and in 1994-95, both periods when large devaluations and resultant high inflation followed periods of exchange rate stability and moderately low inflation. It is likely that these large devaluations led to changes in the way that realizations of inflation and exchange rate depreciation altered expectations of future inflation, which, in turn, led to changes in the coefficients linking past inflation and exchange rates to current inflation. ${ }^{15}$

It is beyond the scope of this paper to model the expectations formation process more explicitly in order to achieve a more stable model. However, while the dynamics in the inflation equation are subject to some instability, the parameters of the long-run solution for the real exchange rate and industrial production are surprisingly constant. To solve for the equilibrium exchange rate

\footnotetext{
${ }^{25}$ Both Edwards (1993) and Santaella and Vela (1996) estimate equations which relate Mexican inflation to lagged inflation and measures of monetary and fiscal stimulus. They find that the coefficient on lagged inflation diminished significantly in the post-1987 period, suggesting that the stabilization program succeeded, to some extent, in moderating inflation expectations and thereby reducing the persistence in inflation. Given the instability of various parameters in the equation shown on Table 5, as well as the results of the breakpoint Chow tests (which indicate 1982 and 1994-95 to be more significant break points in the regression than 1988), I decided not to incorporate into the model the reduction in the coefficient on lagged inflation after 1987.
} 
rer*as a function of detrended industrial production ip, I set the coefficients on the log-changes of variables in the estimated equation to zero and invert the equation:

$$
\begin{aligned}
& \text { rer* }^{*}-\text { constant } /\left({\text { coefficient on } \left.\text { rer }_{-1}\right)-(\text { coefficient on ip }}_{-1}\right) /\left({\text { coefficient on } \left.\text { rer }_{-1}\right) * \text { ip }}^{*}\right. \\
& =-4.24-2.25 * \mathrm{ip}
\end{aligned}
$$

Chart 11 plots the intercept and the slope coefficient shown above, estimated over progressively longer sample periods. As may be seen, the intercept of the rer* equation is quite stable over almost all the sample range, and the slope coefficient also is moderately constant.

Chart 12 plots the estimated rer*, based on the full-sample estimate, over the entire period of study, along with the actual real exchange rate. The chart indicates clearly that during the 1982-87 period, the real exchange rate was much more depreciated than its equilibrium value, consistent (see II.3) with the need to keep the exchange rate super-competitive in the face of adverse shocks to the balance of payments. ${ }^{16}$ After 1987 , the equilibrium real exchange rate appreciated as economic activity recovered from the recession of the previous half-decade. The actual real exchange rate appreciated by an even greater extent in order to reach the level of the equilibrium rate by 1993 , since not only did the equilibrium rate appreciate, but the actual exchange rate started out highly depreciated relative to the equilibrium rate in 1987.

It should be underscored that the 1993-94 exchange rate was at its estimated equilibrium level only in the sense used in this paper, that the demand and supply of non-tradeables were in balance. Given that Mexico's current account balance was nearly 8 percent of GDP in 1994, it is likely that the exchange rate was highly overvalued relative to the level at which both the non-tradeables sector and

${ }^{16} \mathrm{My}$ finding of a persistent gap between actual and equilibrium real exchange rates is analogous in certain respects to findings by de Brouwer and Ericsson (1995) in their analysis of Australian inflation. De Brouwer and Ericsson estimate an error-correction model of Australian prices in which inflation results. in part, from disequilibria in the cointegrating relationship between prices and input costs. They determine that a significant degree of disequilibria--that is, a gap between actual prices and their long-run value as predicted by the cointegrating vector--persisted over their estimation period. 
the current account (or the current account plus sustainable capital inflows) would have been in balance. Warner (1996). using an equilibrium concept similar to the latter--that is, the rate which leads to both internal and external balance--estimates that the peso was overvalued by about 25 percent on the eve of the December 1994 devaluation.

\section{A Decomposition of the Real Appreciation of the Mexican Peso}

Chart 12 makes clear that the appreciation of the equilibrium real exchange rate cannot have been the only factor underlying the actual real exchange rate's appreciation, since the estimated equilibrium real exchange rate appreciated by less than the actual exchange rate between 1987 and 1994. On the other hand, Chart 12 provides little information regarding the relative contribution of inertial and equilibrium factors to the peso's appreciation. In principle, the peso's appreciation could have reflected inertial factors almost exclusively, with it being coincidence alone that the actual real exchange rate stabilized around the estimated equilibrium rate in early 1994.

To evaluate the relative contribution of these different factors to the peso's appreciation, I performed a number of simulation experiments using the estimated inflation model described above. Chart 13 indicates the results of a fully dynamic, in-sample simulation of the model, starting in 1988.1. As shown in the top panel, the model does a reasonable job of tracking the broad contours of inflation performance. The simulated real exchange rate (bottom panel) is based on the simulated path of prices shown in the top panel. While the simulated real exchange rate is persistently more appreciated than its actual level for the first few years, it shows no signs of a more concerted drift.

After calibrating the model so that it reproduced the actual path of inflation and the real exchange rate during 1988.1-1995.12, ${ }^{17}$ I performed two simulation experiments, shown in Chart 14 . In Simulation 1, lagged values of Mexican CPI inflation during 1987 were set to 10 percent at an

\footnotetext{
${ }^{17}$ Specifically, we added the series of residuals from the estimated equation as an additional explanatory variable in order to guarantee that the fully dynamic simulation would track the actual paths of the endogenous variables.
} 
annual rate, compared to actual inflation (at a seasonally adjusted, annual rate) of 188 percent in December 1987. The purpose of this experiment is to evaluate the contribution of inertial inflation to the peso's real appreciation. If inertial inflation made a significant contribution, than the high prestabilization rate of inflation must also have been important to the peso's real appreciation. In fact, as may be seen in Chart 14. when the model is simulated under the much lower pre-stabilization inflation scenario, the resuitant reai exchange rate is more depreciated than the actual rate only for about a year, and then rapidly converges to actual. This suggests that the inertial factors in Mexican infiation were too weak, and the error-correcting factors too strong, ${ }^{18}$ for inertial factors alone to have significantly altered the path of the real exchange rate for more than a limited period. ${ }^{19}$ It should still be noted, however, that the initial sharp appreciation of the peso can be attributed to these inertial factors.

In Simulation 2, we retain the setting of lagged 1987 inflation values to their counterfactual, lower levels, and in addition constrain our measure of detrended industrial production to remain frozen at its trough value of about 9 percent below trend from 1988.4 through the remainder of the sample. The purpose of this experiment is to determine the contribution made to the peso's real appreciation by the growth in aggregate demand following the stabilization period. In Chart 14, the distance between the "Actual" line and the Simulation 2 line represents the contribution of the growth in ip to the real appreciation of the peso. As may be seen, of the total roughly 40 percent real appreciation of the

\footnotetext{
${ }^{18}$ Dornbusch and Werner (1994) estimate a model relating the change in Mexican inflation to the excess of exchange rate depreciation over lagged inflation, and to the lagged real exchange rate. In contrast to the results shown here, they find that the persistence effects of inflation can lead to highly sustained deviations of the real exchange rate from equilibrium (when the nominal exchange rate is fixed). Their results hinge upon an extremely low estimated coefficient on the lagged real exchange rate, which may reflect the shorter sample period for their estimation, their use of quarterly data (which further reduced degrees of freedom), or the highly restrictive nature of their equation's dynamic specification.

${ }^{2}$ The findings by Edwards (1993) and Santaella and Vela (1994) that inflation persistence declined after 1987 only strengthen this conclusion, since our model is estimated using coefficients on lagged inflation estimated over the entire sample period.
} 
peso between 1988.1 and 1994.1, slightly more than half of the movement is accounted for by the growth of output, which is to say, by an appreciation of the real equilibrium exchange rate.

In Simulation 2, both inertial effects and the effects of changes in output, and hence in the equilibrium real exchange rate, are controlled for. Hence. the only factors contributing to the real exchange rate's path in Simulation 2 are transitory impact effects--those of lags of $\Delta p, \Delta e$, and $\Delta p^{*--}$ and the error-correction process moving the actual real exchange rate toward its equilibrium value (which is kept frozen in this simulation at its 1988.4 value). Assuming the transitory impact effects do not explain the broad trends in the real exchange rate, the roughly 20 percent appreciation of the real exchange rate indicated in Simulation 2 is attributable almost solely to the movement of the real exchange rate toward equilibrium from its excessively depreciated level at the start of the stabilization program.

In conclusion, based on our estimated inflation equation, we find that inertial factors only explain the initial sharp real appreciation of the peso immediately following the stabilization program, but thereafter had no discernable effect on the real exchange rate's level. Of the real exchange rate appreciation that occurred between 1988 and 1994, about half was attributable to an appreciation of the real equilibrium rate, due to increases in economic activity, and about half was due to the adjustment of the real exchange rate from its off-equilibrium position at the end of 1987 .

\section{Implications for the Future Mexican Exchange Rate Policy}

The preceding analysis of the effects of the level of the real exchange rate on the rate of inflation has important implications for the choice of exchange rate policy in Mexico. At present, the nominal exchange rate is floating freely, and in recent months it has remained relatively stable, even as domestic prices have continued to rise. In response to concerns that the real exchange rate will continue to appreciate in the future, thereby eroding recent improvements in trade performance, some observers have called for the government to intervene to depreciate the nominal exchange rate in line 
with domestic price inflation. thereby keeping the peso highly competitive. Conversely, other analysts have viewed the recent stability of the nominal peso as a favorable development that will allow inflation to decline more rapidly, and believe that the government should continue to follow policies that lower the rate of exchange rate depreciation. I show below, however, that policies that target exclusively either exchange rate competitiveness or low inflation are likely to generate undesirable outcomes for the variable that is not targeted.

In this section, $i$ consider forecasts of inflation and the real exchange rate over the next two years under two different scenarios. In either scenario, I assume that detrended industrial production remains at its January 1996 (the latest available data) level, as shown in the bottom panel of Chart $15 .^{20}$ The first scenario, which represents a strong anti-inflation policy, assumes that the peso wil! depreciate relatively gradually, from its current value of about 7.5 pesos/dollar to 8 pesos/dollar at the end of 1996 and to 8.6 pesos/dollar at the end of 1997; this implies a very low monthly rate of depreciation, as shown in the top panel of Chart 15 .

Based on this assumed path of the exchange rate, Chart 16 indicates that the monthly rate of inflation will decline throughout most of the forecast period (which starts in April 1996), reaching about 11 percent (at an annual rate) by the end of 1997 . Even so, inflation will remain high initialiy, with the 12-month inflation rate registering 38 percent in 1996 before dropping to 23 percent in $1997 .^{21}$ Note, on the bottom panel, that by the end of the forecast period, the real exchange rate has

${ }^{20}$ Most observers agree that Mexican economic activity--as represented by GDP--remains we!! below its potential value, and hence is likely to continue to grow over time. However, as a result of recent sharp increases, Mexican industrial production jumped above its trend level in January 1996, and hence is already close to its mean (detrended) value during the 1990-94 period. Hence, I assume that industrial production will grow only at its trend value of about 2 percent annually over the forecast period.

${ }^{21}$ These inflation rates are somewhat higher than most private forecasts, which are centered around 30 percent (December over December) for 1996. One possibility is that the recent sharp recovery of industrial production, which rose to above its trend level in January 1996, may overstate the recovery of the economy as a whole--most forecasters do not expect Mexican real GDP to regain 
converged nearly to its equilibrium value. Considering that in 1994 , a real exchange rate at this level was associated with a very large trade and current account deficit, this suggests that an exchange rate policy geared exclusively toward disinflation could lead to a resumption of large external imbalances.

In the second scenario, shown on Chart 17, I assume that the Mexican authorities target the real exchange rate at about its level in March 1996 by setting the rate of depreciation of the peso equal to the difference between Mexican and U.S. inflation rates in the previous month. (The authorities observe inflation with a lag.) As shown on the bottom panel, this policy has the effect of freezing in place the very large gap between the actual and equilibrium real exchange rates that existed at the start of the forecast period. This large gap, in turn, results in very high rates of inflation--equivalent to about 95 percent at an annual rate--by the end of the forecast horizon. (It takes time for the inflation rate to rise to that high rate, given the persistence in inflation.) Hence, under this scenario, very positive trade performance is maintained at the cost of much higher inflation.

\section{Conclusion}

The most important results of this research are summarized as follows. First, the estimated equation for Mexican inflation confirms the applicability of the tradeables/non-tradeables framework to analyzing real exchange rate dynamics. The levels of both the real exchange rate and detrended output were significant determinants of the rate of inflation. Based on the estimated model, the parameters of the function linking output to the equilibrium real exchange rate--that is, the rate at which the supply and demand for non-tradeables is in balance--appear to have remained relatively stable over the sample period.

Second, consistent with my initial speculation, the actual real exchange rate was considerably more depreciated than the estimated equilibrium real exchange rate during 1982-87. By 1993-94, the

its 1994 level until 1997 at the earliest. Hence, the inflation forecast may be predicated on a higher level of economic activity in 1996-97 than will actually take place. 
real exchange rate had converged to its estimated equilibrium level. By this, I mean that the real exchange rate had ceased to a factor exerting upward pressure on domestic prices, not that the real exchange rate was at a sustainable level from the standpoint of balance-of-payments equilibrium. In fact, the size of Mexico's current account deficit in 1994 suggests that the exchange rate probably was quite overvalued relative to the level required for sustained external balance.

Third, by simulating the infiation equation under different assumptions, I was able to decompose the real appreciation of the peso from 1988 through 1994 into three components: that attributable to an appreciation of the equilibrium real exchange rate, that attributable to inertial inflation. and that attributable to an adjustment of the real exchange rate to its equilibrium level. I found that the effects of inertial inflation in appreciating the real exchange rate were quite temporary, lasting only about a year after the stabilization program was implemented. Of the real appreciation that took place by 1994, about half was attributable to the appreciation of the equilibrium exchange rate, and about half reflected the appreciation of the real exchange rate to its equilibrium level (as of the time the program was first implemented).

Finally, the significance of the level of the real exchange rate in determining the rate of inflation has important consequences for exchange rate policy. The model points to a tradeoff between the goals of a competitive exchange rate and of low inflation, even at relatively moderate rates of output growth. If future rates of exchange rate depreciation remain low, inflation should decline gradually, but the real exchange rate will appreciate and trade performance is likely to deteriorate considerably. Conversely, if the real exchange rate is targeted at its current highly competitive level, model simulations indicate that inflation would rise significantly over the next few years.

It is beyond the scope of this paper to address the problem of reconciling the objectives of internal and externa! imbalance in Mexico. However, is seems likely that the solution to this problem would involve two elements. First, exchange rate policy might usefully pursue a middle ground 
involving more exchange rate depreciation than in the anti-inflation scenario, but less depreciation than in the real exchange-rate-target scenario. Since financial markets at present are acutely aware of the tradeoffs between inflation and competitiveness, the future path of the exchange rate under the current floating-rate regime, if coupled wth appropriate fiscal and monetary policies, might well be consistent with such a "middle ground" policy. Second, structural reforms that raise the savings rate and increase productivity would improve the terms of the tradeoff between inflation and trade performance, allowing for lower inflation and higher output growth while maintaining gains to trade competitiveness. 


\section{REFERENCES}

Calvo, Guillermo and Carlos A. Vegh (1993), "Exchange Rate Based Stabilization under Imperfect Credibility," in Helmut Frisch and Andreas Worgotter, Open Economy Macroeconomics, London: MacMillan, 3-28.

Calvo, Guillermo and Carlos A. Vegh (1994), "Stabilization Dynamics and Backward-looking Contracts," Journal of Development Economics, 43: 59-84.

Calvo, Guillermo and Enrique G. Mendoza (1996), "Mexico's Balance-of-Payments Crisis: A Chronicle of a Death Foretold," Journal of International Economics, forthcoming.

Dornbusch, Rudiger (1980), Open Economy Macroeconomics, New York: Basic Books. , and Allejandro Werner (1994), "Mexico: Stabilization, Reform. and No Growth," Brookings Papers on Economic Activity, 1: 253-315.

de Brouwer, Gordon and Neil R. Ericsson (1995), "Modelling Inflation in Australia," International Finance Discussion Paper No. 530, Board of Governors of the Federal Reserve System, Washington, D.C.

Erceg, Christopher J., and Andrew T. Levin (1996), "Structures Investment and the Dynamic Behavior of the Real Exchange Rate," working paper, Board of Governors of the Federal Reserve System, Washington, D.C.

Edwards, Sebastian (1993), "Exchange Rates, Inflation and Disinflation: Latin American Experiences," NBER Working Paper No. 4320, Cambridge, MA.

Gil-Diaz, Francisco, and Agustin Carstens (1995), "Some Hypotheses Related to the Miexican 1994-95 Crisis," Banco de Mexico, Documento No. 9601.

Kiguel, Miguel, and Nissan Liviatan (1992), "The Business Cycle Associated with Exchange Rate Based Stabilization," World Bank Economic Review, 6: 279-305.

Mendoza, Enrique G., and Martin Uribe (1996), "The Syndrome of Exchange-Rate-Based Stabilizations and the Uncertain Duration of Currency Pegs," International Finance Discussion Paper No. 548, Board of Governors of the Federal Reserve System, Washington, D.C.

Perez-Lopez Elguezabal, Alejandro (1995), "Un Modelo de Cointegracion Para Prognosticar el PIB de Mexico," Banco de Mexico, Documento de Investigacion No. 71.

Rebelo, Sergio and Carlos A. Vegh (1995), "Real Effects of Exchange-Rate-Based Stabilizations: An Analysis of Competing Theories," NBER Macro Annual, National Bureau of Economic Research, Cambridge: MA. 
Reinhart. Carmen M., and Carlos A. Vegh (1995), "Nominal Interest Rates, Consumption Booms, and Lack of Credibility: A Quantitative Examination," Journal of Development Economics, forthcoming.

Rodriguez, Carlos Alfredo (1982), "The Argentine Stabilization Program of December 20th," World Development, 10: 801-811.

Roldos, Jorge E. (1995), "Supply-Side Effects of Disinflation Programs," IMF Staff Papers, 42: 158183.

Uribe, Martin (1995), "Exchange-Rate-Based Inflation Stabilization: The Initial Real Effects of Credible Plans," International Finance Discussion Paper No. 503, Board of Governors of the Federal Reserve System, Washington, D.C.

Salter, W. E. (1959), "Internal and External Balance: The Role of Prices and Expenditure Effects," Economic Record, 35: 226-38.

Santaella, Julio A., and Abraham E. Vela (1996), "The 1987 Mexican Disinflation Program: An Exchange Rate-Based Stabilization?" International Monetary Fund, IMF Working Paper WP/96/24.

Swan, T. (1960), "Economic Control in a Dependent Economy," Economic Record, 36: 51-66.

Vegh, Carlos A. (1992), "Stopping High Inflation: An Analytical Overview," IMF Staff Papers, 39: 626-695.

Warner, Andrew M. (1996), "Nominal Exchange Rate Equilibria in the Non-traded Model: Mexico 1994," working paper, Harvard Institute for International Development, Cambridge, M.A. 
Table 1: Augmented Dickey-Fuiler Tests for Unit Roots

\begin{tabular}{||l|l|l|l|l|l||}
\hline \hline & $\mathrm{p}$ & $\mathrm{e}$ & $\mathrm{p}^{*}$ & rer & ip \\
\hline $\mathrm{I}(1)$ & -2.14 & -2.26 & -1.03 & -2.58 & -3.04 \\
& $(-.00)$ & $(-.01)$ & $(-.00)$ & $(-.05)$ & $(-.08)$ \\
& $(5)$ & $(5)$ & $(7)$ & $(5)$ & $(3)$ \\
\hline $\mathrm{I}(2)$ & -2.50 & $-3.28^{*}$ & $-3.89^{*}$ & $-4.65^{* *}$ & $-4.79^{* *}$ \\
& $(-.09)$ & $(-.40)$ & $(-.36)$ & $(-.77)$ & $(-1.12)$ \\
& $(11)$ & $(4)$ & $(6)$ & $(4)$ & $(9)$ \\
\hline $\mathrm{I}(3)$ & $-3.41^{*}$ & & & & \\
& $(-1.17)$ & & & & \\
& $(10)$ & & & & \\
\hline
\end{tabular}

Notes

1. For the variable $\mathrm{x}$, the augmented Dickey=Fuller statistic is the t-ratio on $\pi$ from the regression:

$\Delta x_{7}=\pi x_{i \cdot j}+\beta_{i} \Delta x_{i-i}+\beta_{2} \Delta x_{i-2}+\ldots+\beta_{i n} \Delta x_{i-\pi}+$ Constant + Seasonal Dummies.

For a given variable and null order of integration, three statistics are reported: the augmented Dickey-Fuller statistic, the estimated coefficient $(\pi)$ on the lagged variable $x_{1-1}$, and the number of lags on the dependent variable $n$. The number of lags was chosen by estimating the regression separately for 0 lags through 13 lags, and choosing the regression with the highestorder lag whose t-statistic exceeded 2.

2. For industrial production ip, the non-detrended value of log industrial production was used, and a time trend was included separately in the regression equation described above. The critical value used was adjusted for inclusion of the time trend.

2. The estimation sample is $1981.4-1995.12$.

3. Here and elsewhere in this paper, asterisks * and ** denote rejection at the $5 \%$ and $1 \%$ critical values. 
Table 2: Cointegration Analysis for $p, p^{\star}$, e, and ip

\begin{tabular}{||l|l|l|l|l||}
\hline Eigenvalue & .154 & .105 & .055 & .028 \\
\hline Null Hypothesis & $\mathrm{r}=0$ & $\mathrm{r}<=1$ & $\mathrm{r}<=2$ & $\mathrm{r}<=3$ \\
\hline$\lambda \max$ & $29.66^{*}$ & 19.61 & 10.02 & $5.09^{*}$ \\
\hline $\begin{array}{l}\lambda \max \text { with d.f. } \\
\text { adjustment }\end{array}$ & 25.64 & 16.95 & 8.66 & $4.40^{*}$ \\
\hline $\begin{array}{l}\lambda \max 95 \% \\
\text { critical value }\end{array}$ & 27.1 & 21.0 & 14.1 & 3.8 \\
\hline \begin{tabular}{l}
$\lambda$ trace \\
\hline $\begin{array}{l}\lambda \text { trace with d.f. } \\
\text { adjustment }\end{array}$
\end{tabular} & $55.64^{* *}$ & $30.00^{*}$ & 13.06 & $5.09^{*}$ \\
\hline $\begin{array}{l}\lambda \text { trace 95\% } \\
\text { critical value }\end{array}$ & 47.2 & 29.7 & 15.4 & $3.40^{*}$ \\
\hline
\end{tabular}

Standardized Eigenvectors

\begin{tabular}{|l|l|l|l||}
\hline $\mathrm{p}^{*}$ & $\mathrm{e}$ & ip & $\mathrm{p}$ \\
\hline 1.000 & .530 & 1.689 & -.568 \\
\hline 2.128 & 1.000 & .537 & -1.080 \\
\hline-2.681 & -.510 & 1.000 & .789 \\
\hline 6.309 & -1.520 & -3.695 & 1.000 \\
\hline
\end{tabular}

Notes

1. The vector autoregression includes 6 lags of each variables, a constant term, and seasonal dummies.

2. The statistics $\lambda \max$ and $\lambda$ trace are Johansen's maximal eigenvalue and trace eigenvalue statistics for testing cointegration. Statistics with degrees-of-freedom adjustments also are shown.

3. The estimation sample is $1981.4-1995.12$. 
Table 3: Cointegration Analysis for $p, p^{*}$, and $e$

\begin{tabular}{|c|c|c|c|}
\hline Eigenvalue & .092 & .057 & .032 \\
\hline Null Hypothesis & $r=0$ & $\mathrm{r}<=1$ & $r<=2$ \\
\hline$\lambda \max$ & 17.13 & 10.36 & $5.70^{*}$ \\
\hline $\begin{array}{l}\lambda \max \text { with d.f. } \\
\text { adjustment }\end{array}$ & 15.39 & 9.31 & $5.12^{*}$ \\
\hline $\begin{array}{l}\lambda \max 95 \% \\
\text { critical value }\end{array}$ & 21.0 & 14.1 & 3.8 \\
\hline$\lambda$ trace & $33.20^{*}$ & $16.07^{*}$ & $5.70^{*}$ \\
\hline $\begin{array}{l}\lambda \text { trace with d.f. } \\
\text { adjustment }\end{array}$ & $29.83^{*}$ & $14.43^{*}$ & $5.12^{*}$ \\
\hline $\begin{array}{l}\lambda \text { trace } 95 \% \\
\text { critical value }\end{array}$ & 29.7 & 15.4 & 3.8 \\
\hline
\end{tabular}

Standardized Eigenvectors

\begin{tabular}{||l|l|l||}
\hline $\mathrm{p}^{*}$ & $\mathrm{e}$ & $\mathrm{p}$ \\
\hline 1.000 & .376 & -.410 \\
\hline-2.543 & 1.000 & -.808 \\
\hline-3.543 & -.717 & 1.000 \\
\hline
\end{tabular}

\section{Notes}

1. The vector autoregression includes 6 lags of each variables, a constant term, and seasonal dummies.

2. The statistics $\lambda \max$ and $\lambda$ trace are Johansen's maximal eigenvalue and trace eigenvalue statistics for testing cointegration. Statistics with degrees-of-freedom adjustments also are shown.

3. The estimation sample is $1981.4-1995.12$. 
Table 4: Cointegration Analysis for rer and ip

\begin{tabular}{||l|l|l||}
\hline Eigenvalue & .095 & .030 \\
\hline Null Hypothesis & $\mathrm{r}=0$ & $\mathrm{r}<=1$ \\
\hline$\lambda \max$ & $17.60^{*}$ & $5.45^{*}$ \\
\hline $\begin{array}{l}\lambda \max \text { with d.f. } \\
\text { adjustment }\end{array}$ & $16.40^{*}$ & $5.08^{*}$ \\
\hline $\begin{array}{l}\lambda \max 95 \% \\
\text { critical value }\end{array}$ & 14.1 & 3.8 \\
\hline $\begin{array}{l}\lambda \text { trace } \\
\text { trace with d.f. } \\
\text { adjustment }\end{array}$ & $21.48^{* *}$ & $5.45^{*}$ \\
\hline $\begin{array}{l}\lambda \text { trace 95\% } \\
\text { critical value }\end{array}$ & 15.4 & $5.08^{*}$ \\
\hline \hline
\end{tabular}

Standardized Eigenvectors

\begin{tabular}{||l|l|}
\hline ip & rer \\
\hline 1.000 & .241 \\
\hline-.858 & 1.000 \\
\hline
\end{tabular}

Notes

1. The vector autoregression includes 6 lags of each variables, a constant term, and seasonal dummies.

2. The statistics $\lambda \max$ and $\lambda$ trace are Johansen's maximal eigenvalue and trace eigenvalue statistics for testing cointegration. Statistics with degrees-of-freedom adjustments also are shown.

3. The estimation sample is $1981.4-1995.12$. 
Table 5: Estimation Results for Single-Equation Inflation Model

Dependent Variable: $\Delta \mathrm{p}$

\begin{tabular}{|c|c|c|c|}
\hline & OLS & OLS-NSA & IV \\
\hline Constant & $\begin{array}{c}0.16 \\
(4.94)[3.60]\end{array}$ & $\begin{array}{c}0.19 \\
(5.05)\end{array}$ & $\begin{array}{c}0.16 \\
(4.82)\end{array}$ \\
\hline rer. $_{-1}$ & $\begin{array}{c}0.04 \\
(4.95)[3.60]\end{array}$ & $\begin{array}{c}0.04 \\
(4.80) \\
\end{array}$ & $\begin{array}{c}0.04 \\
(4.82)\end{array}$ \\
\hline $\mathrm{ip}_{.1}$ & $\begin{array}{c}0.08 \\
(4.20)[2.98]\end{array}$ & $\begin{array}{c}0.09 \\
(3.61) \\
\end{array}$ & $\begin{array}{c}0.08 \\
(4.20)\end{array}$ \\
\hline$\Delta \mathrm{p}_{-1}$ & $\begin{array}{c}0.50 \\
(7.88)[3.88] \\
\end{array}$ & $\begin{array}{r}0.57 \\
(7.91) \\
\end{array}$ & $\begin{array}{c}0.51 \\
(7.23)\end{array}$ \\
\hline$\Delta \mathrm{p}_{.2}$ & $\begin{array}{c}0.18 \\
(3.11)[1.62] \\
\end{array}$ & $\begin{array}{c}0.07 \\
(1.09) \\
\end{array}$ & $\begin{array}{c}0.18 \\
(3.04) \\
\end{array}$ \\
\hline$\Delta \mathrm{p}_{-11}$ & $\begin{array}{c}0.21 \\
(3.51)[2.63] \\
\end{array}$ & $\begin{array}{c}0.14 \\
(2.06) \\
\end{array}$ & $\begin{array}{c}0.21 \\
(3.52) \\
\end{array}$ \\
\hline$\Delta \mathrm{p}_{.12}$ & $\begin{array}{c}-0.21 \\
(-3.46)[-2.88]\end{array}$ & $\begin{array}{c}-0.12 \\
(-1.82)\end{array}$ & $\begin{array}{c}-0.21 \\
(-3.47)\end{array}$ \\
\hline$\Delta \mathrm{e}$ & $\begin{array}{c}0.08 \\
(8.04)[2.71]\end{array}$ & $\begin{array}{c}0.09 \\
(7.10)\end{array}$ & $\begin{array}{l}0.07 \\
(2.64)\end{array}$ \\
\hline$\Delta \mathrm{e}_{-1}$ & $\begin{array}{c}-0.02 \\
(-1.66)[-0.60]\end{array}$ & $\begin{array}{c}-0.03 \\
(-1.58)\end{array}$ & $\begin{array}{c}-0.02 \\
(-1.45) \\
\end{array}$ \\
\hline$\Delta e_{.3}$ & $\begin{array}{c}0.03 \\
(2.66)[1.05] \\
\end{array}$ & $\begin{array}{c}0.02 \\
(1.37) \\
\end{array}$ & $\begin{array}{c}0.03 \\
(2.61) \\
\end{array}$ \\
\hline$\Delta \mathrm{e}_{.9}$ & $\begin{array}{c}0.02 \\
(2.12)[1.18] \\
\end{array}$ & $\begin{array}{c}0.01 \\
(1.02) \\
\end{array}$ & $\begin{array}{c}0.02 \\
(2.10) \\
\end{array}$ \\
\hline$\Delta \mathrm{p}^{*}{ }_{22}$ & $\begin{array}{c}0.54 \\
(2.74)[1.97]\end{array}$ & $\begin{array}{c}0.57 \\
(2.16)\end{array}$ & $\begin{array}{c}0.53 \\
(2.74)\end{array}$ \\
\hline Adjusted R-squared & 0.90 & 0.86 & 0.90 \\
\hline Regression Standard Error & 0.008 & 0.010 & .008 \\
\hline Durbin-Watson Statistic & 2.05 & 2.07 & 2.05 \\
\hline AR & $F(7,172)=1.15$ & $F(7,161)=0.73$ & $\operatorname{Chi}^{2}(7)=8.04$ \\
\hline $\mathrm{ARCH}$ & $\mathrm{F}(7,165)=4.30^{* *}$ & $F(7,154)=1.41$ & $\mathrm{~F}(7,165)=4.49 * *$ \\
\hline $\mathrm{Xi}^{2}$ & $F(22,156)=7.82^{* *}$ & $F(33,134)=2.84^{* *}$ & $F(22,1156)=7.9^{* *}$ \\
\hline Normality & $\operatorname{Chi}^{2}(2)=18.10^{* *}$ & $\mathrm{Chi}^{2}(2)=49.76^{* *}$ & $\operatorname{Chi}^{2}(2)=20.51^{* *}$ \\
\hline
\end{tabular}

T-statistics in parentheses; heteroscedasticity consistent t-statistics in brackets.

${ }^{*}\left({ }^{* *}\right)$ indicates significant at 5\% (1\%). [Applies to statistics below the double line only.] 


\section{Chart 1. Real Multilateral Exchange Rates}
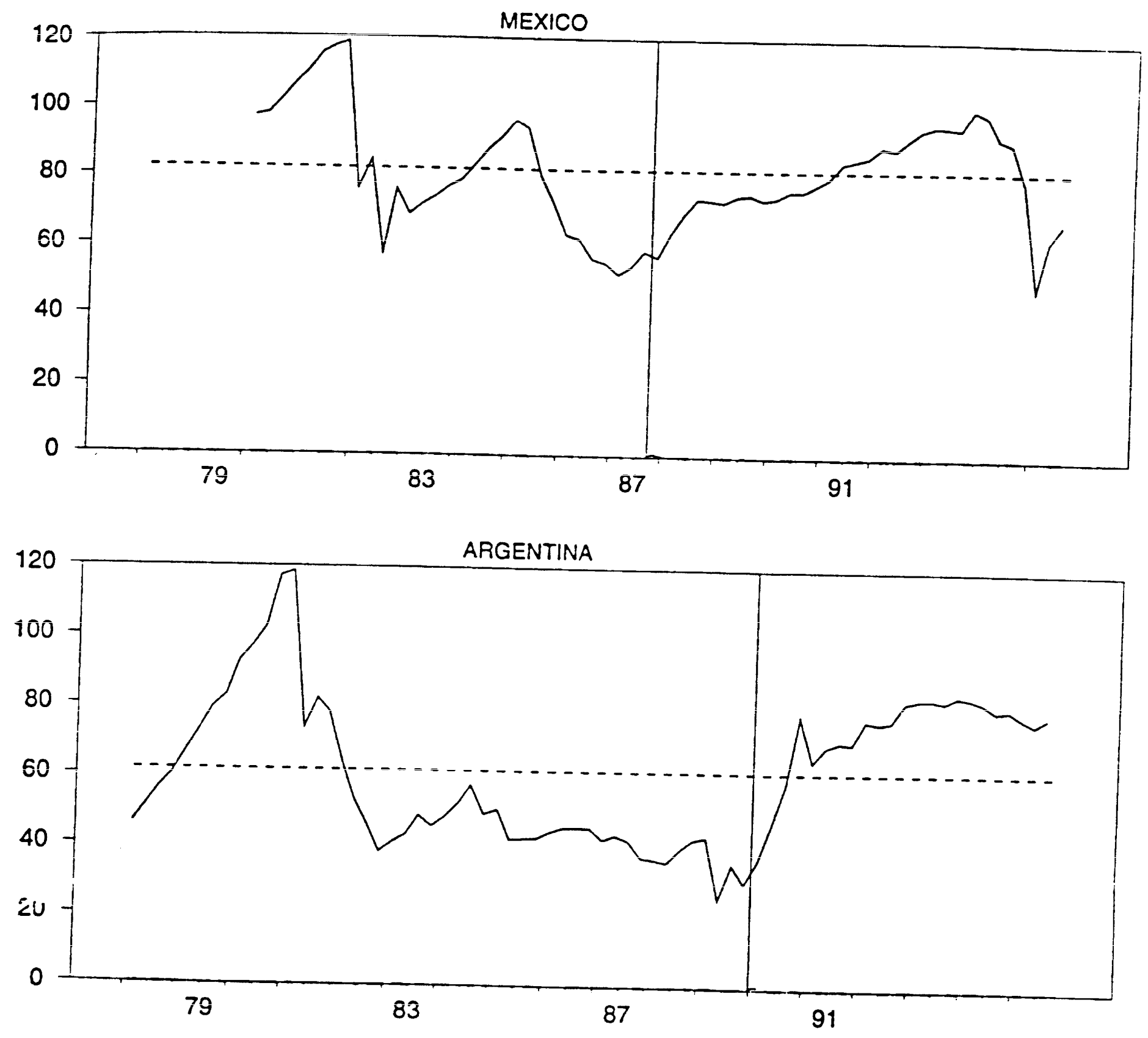

Notes: 1. Verical line indicates stan of exchange-rate based stabilization.

2. Dashed horizontal line indicates mean average of series. 
-40 -

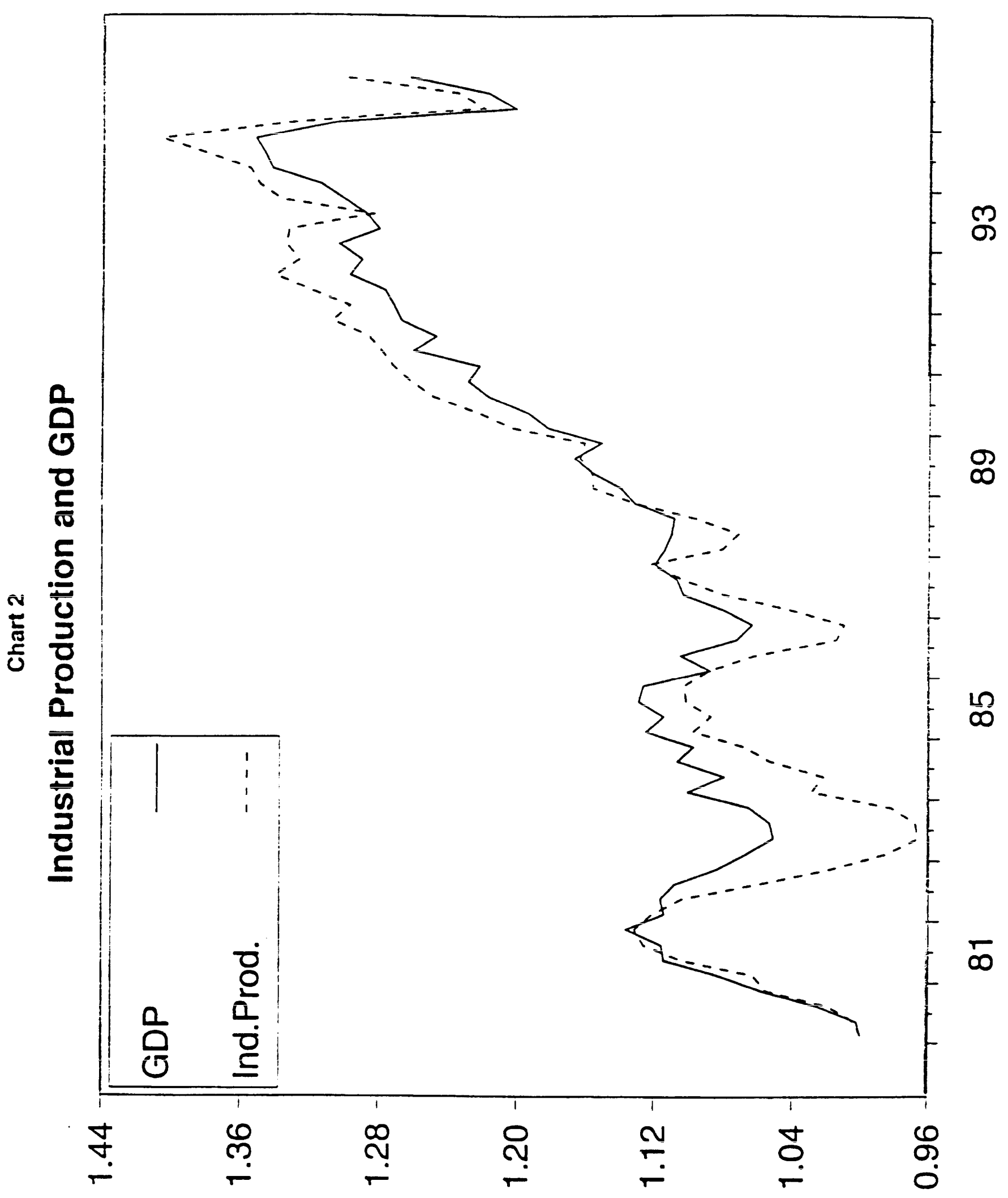




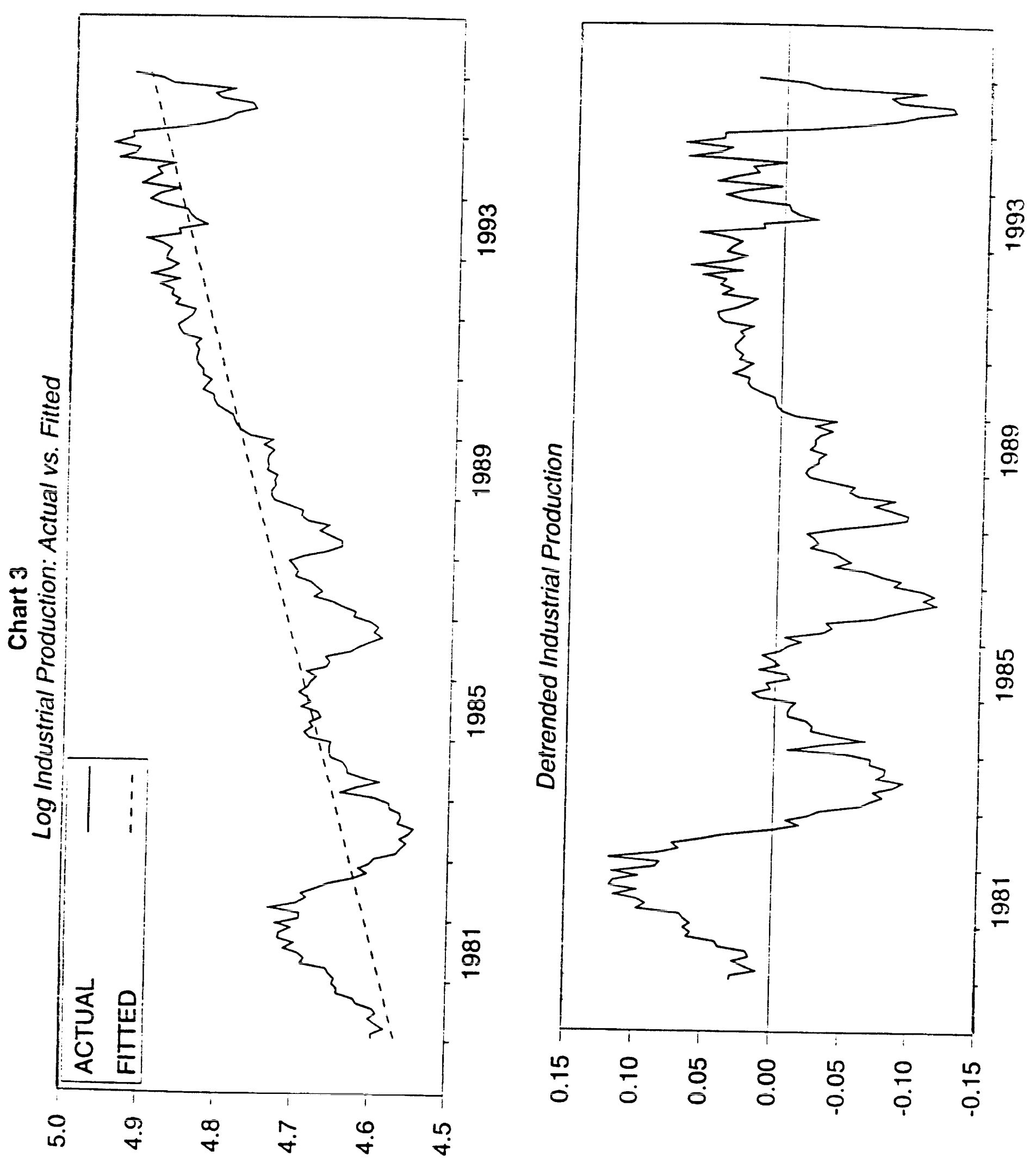




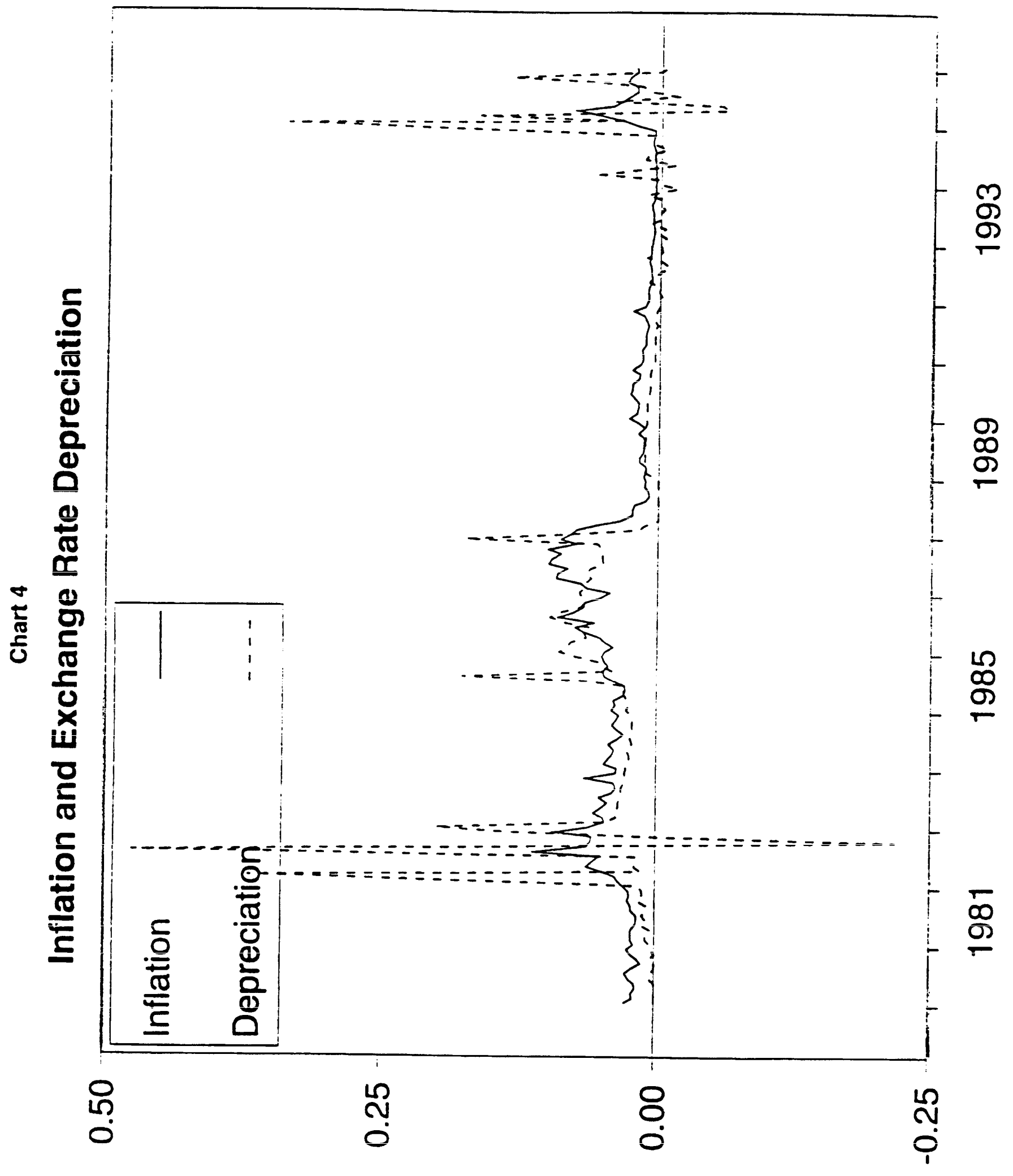




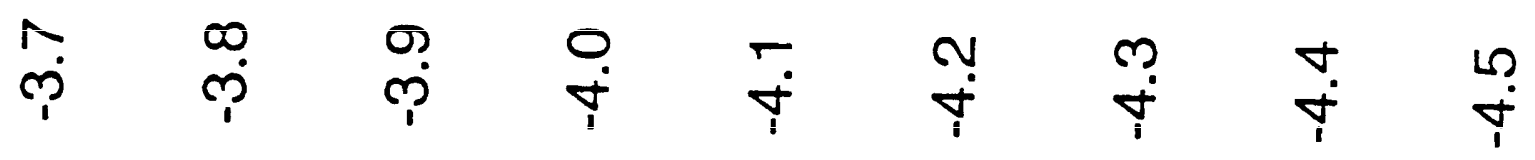

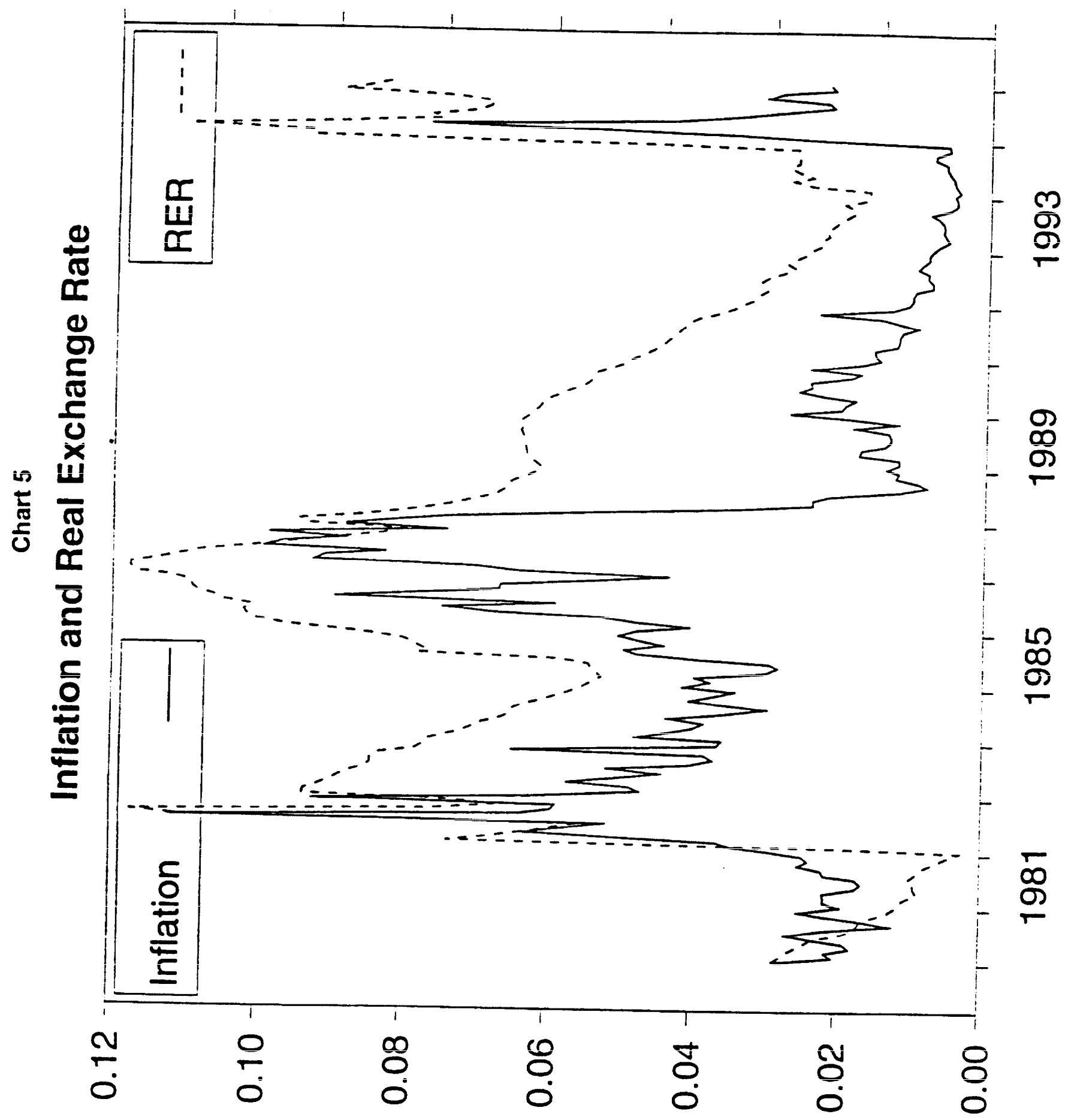


$-44-$

\begin{tabular}{lllllll}
1 & 0 & 0 & 0 & 0 & 0 & \multicolumn{1}{l}{} \\
0 & 0 & 0 & 0 & 0 & 0 & 0
\end{tabular}

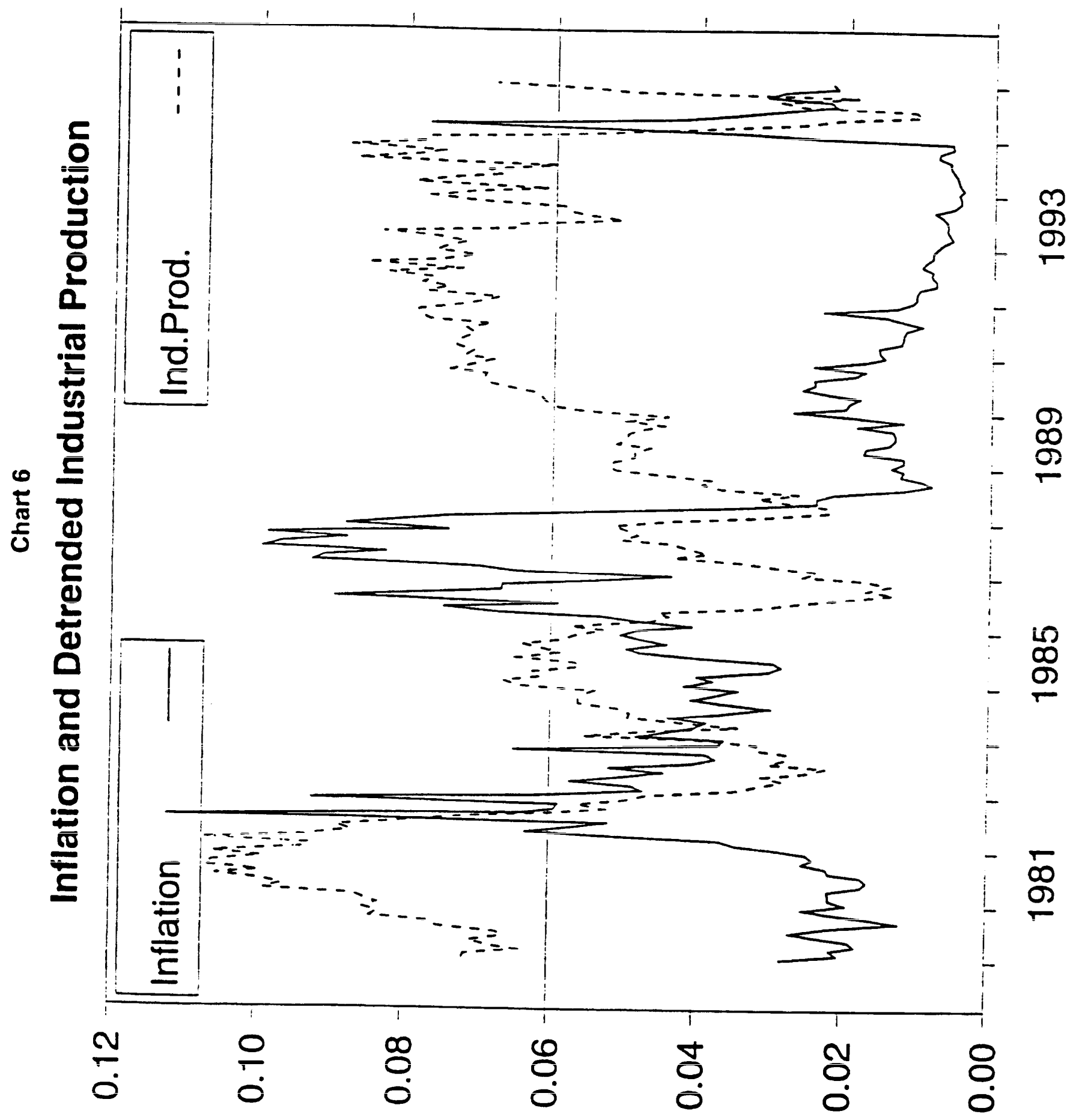


$-45-$

$\begin{array}{lllllll}1 & 0 & 0 & 0 & 0 & 0 & 0 \\ 0 & 0 & 0 & 0 & 0 & 0 & 0\end{array}$

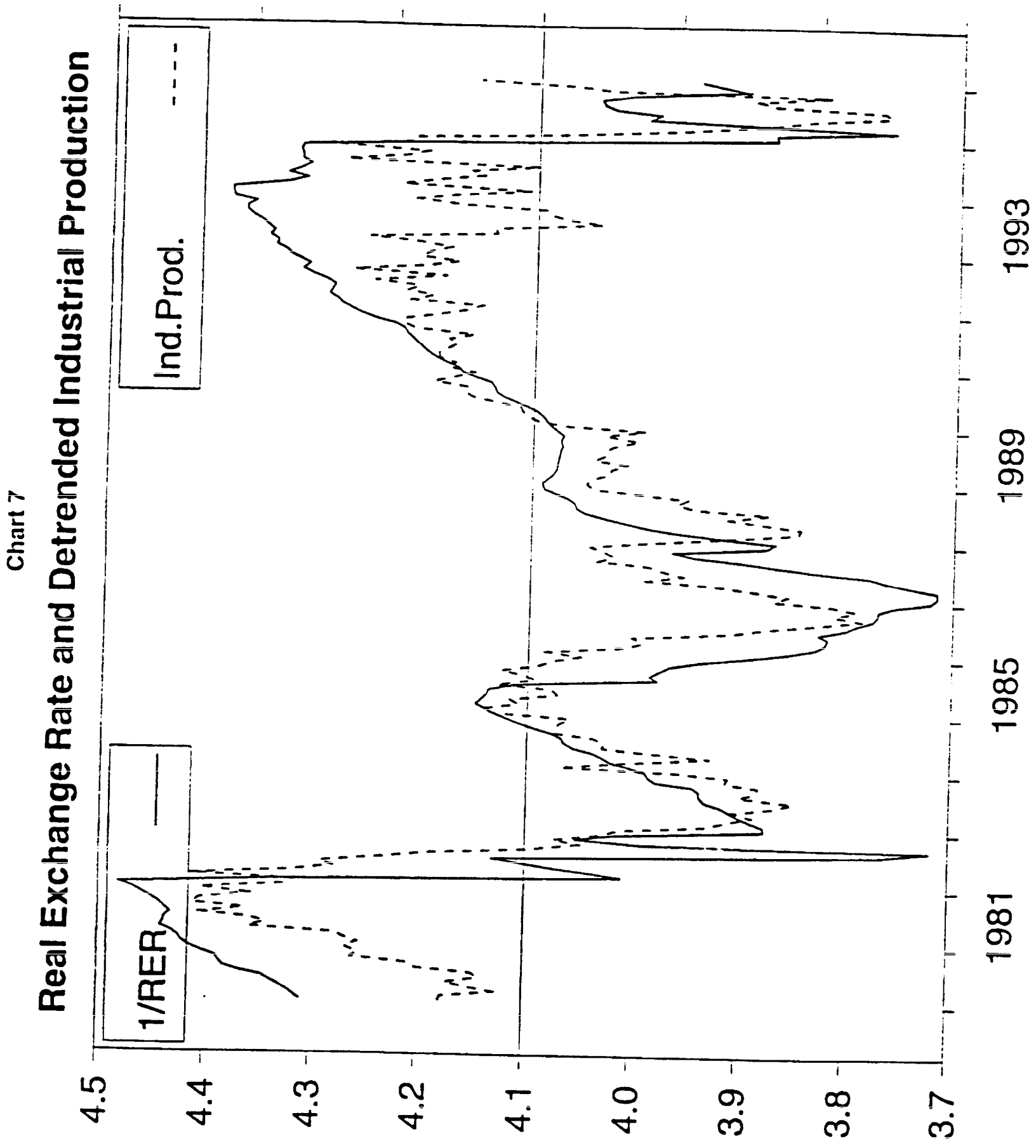



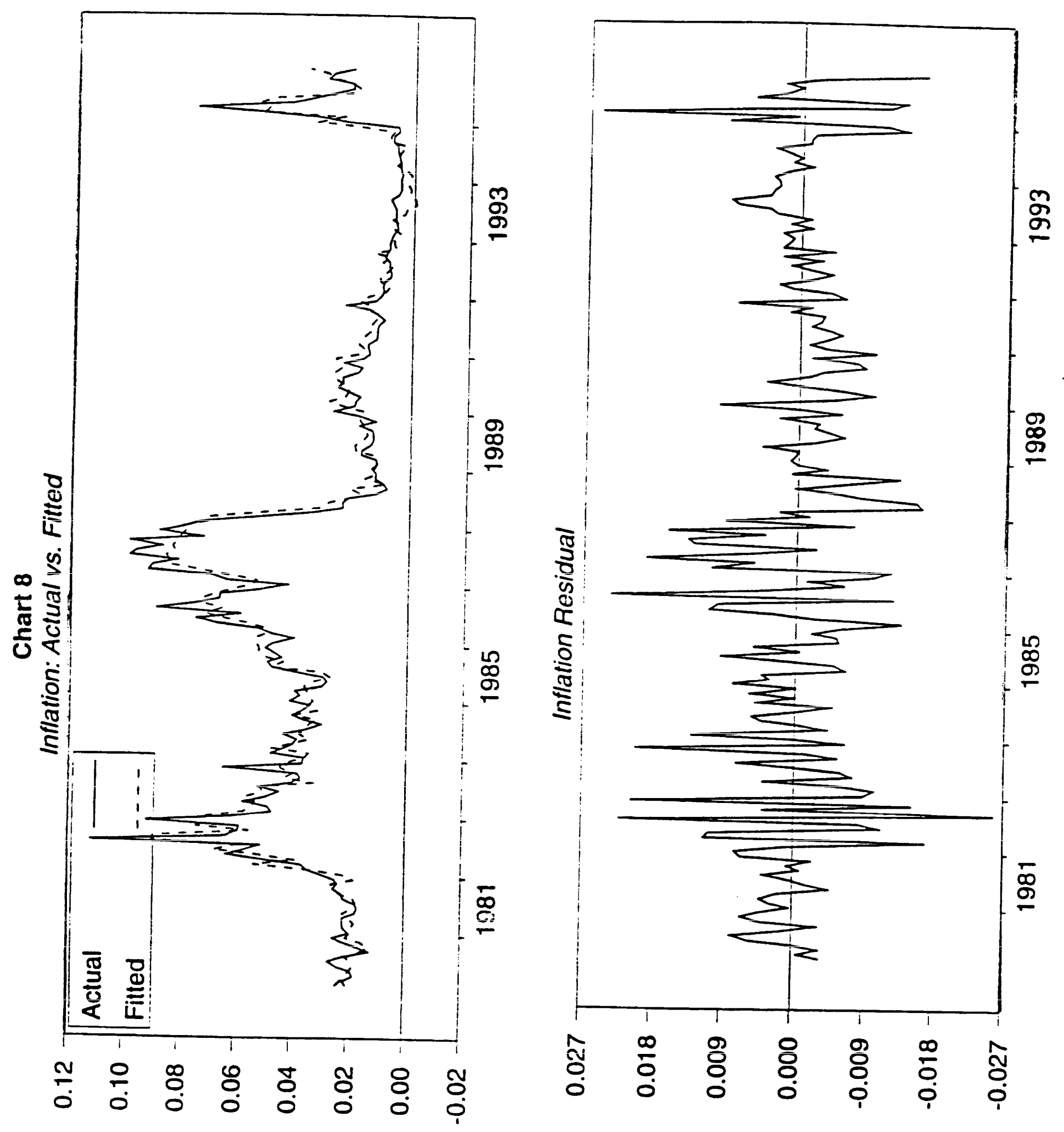


\section{Chart 9. Parameter Constancy: OLS Inflation Regression}
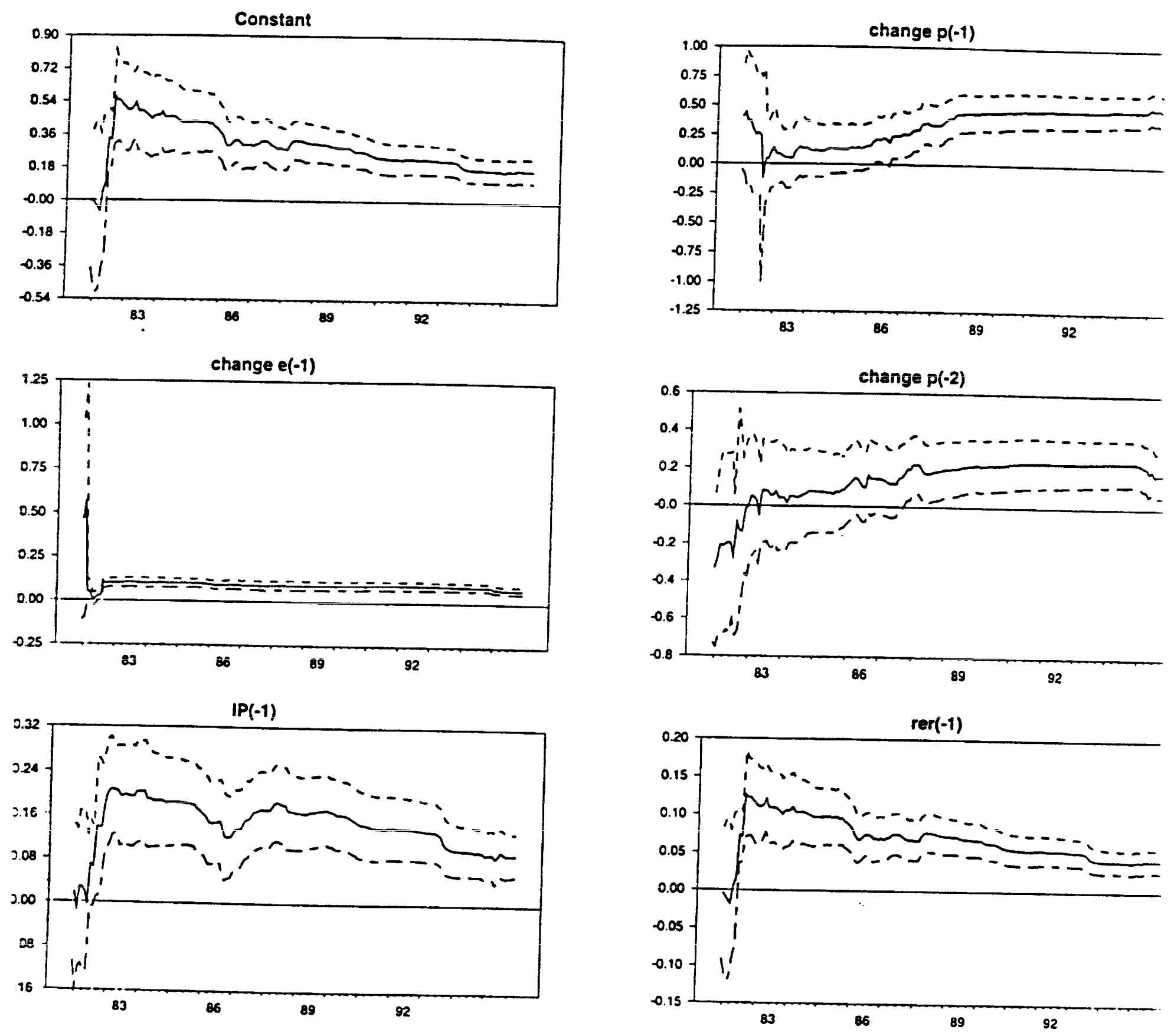


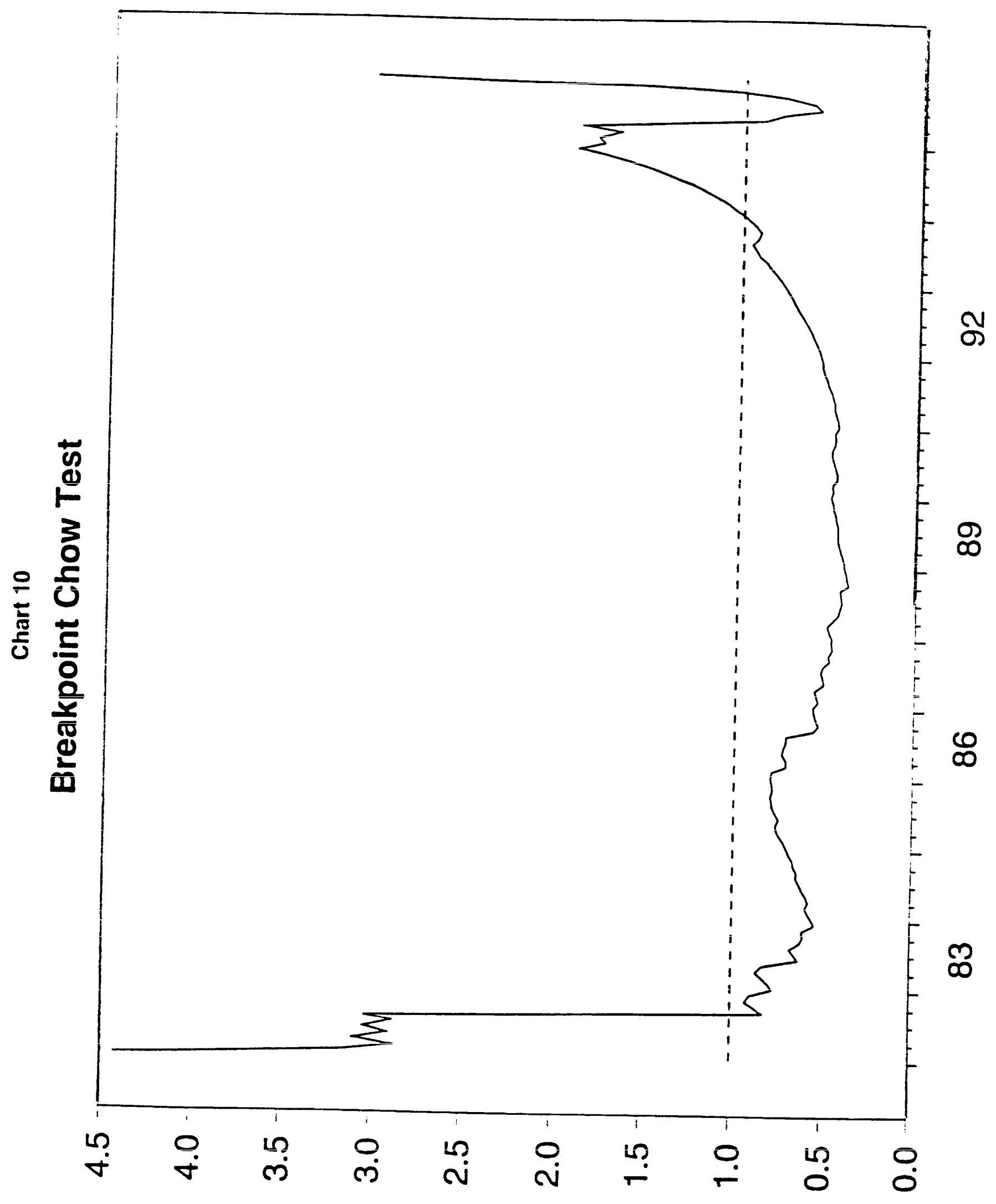




\section{Chart 11}

CONSTANT/coef. on rer(-1)
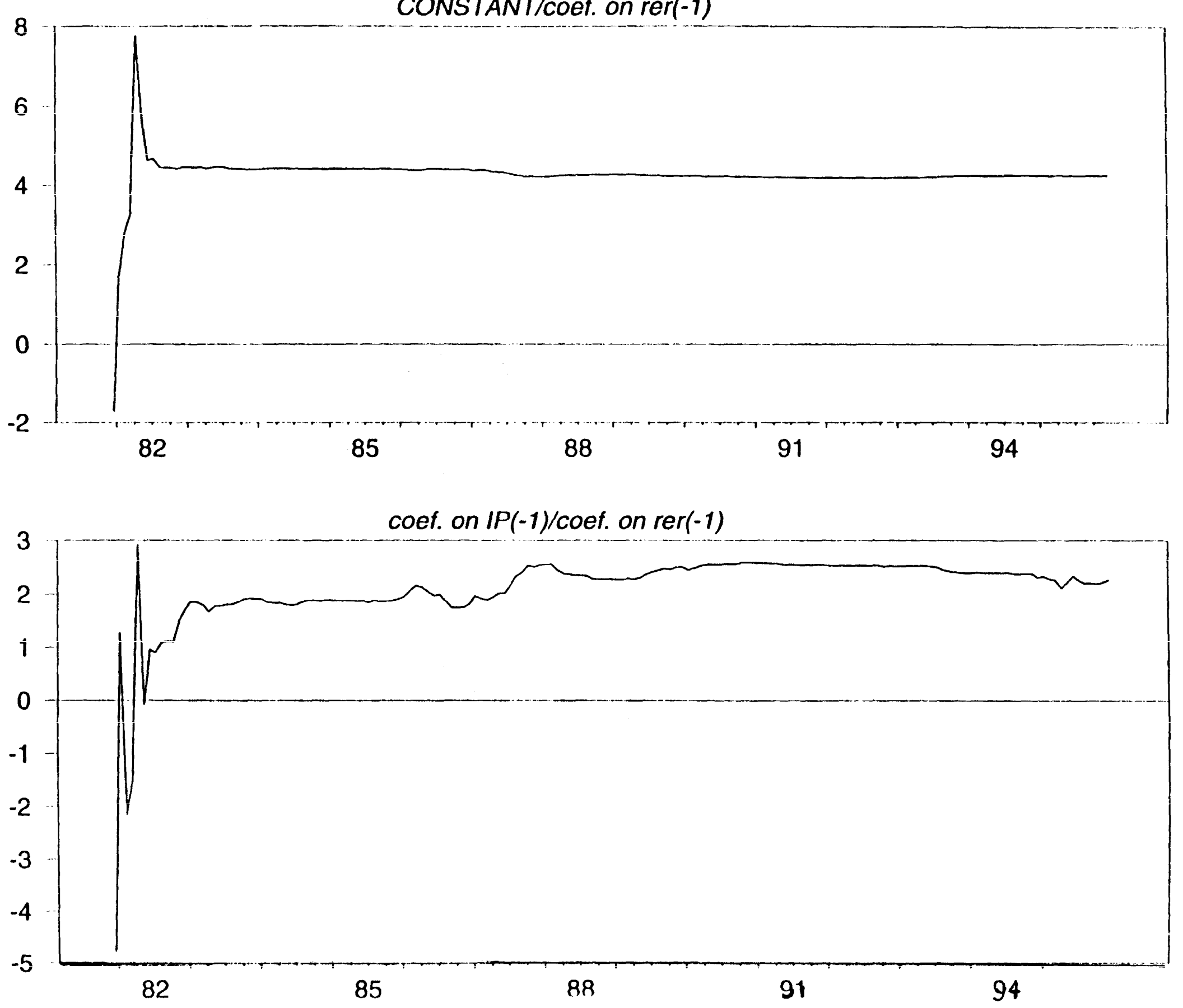


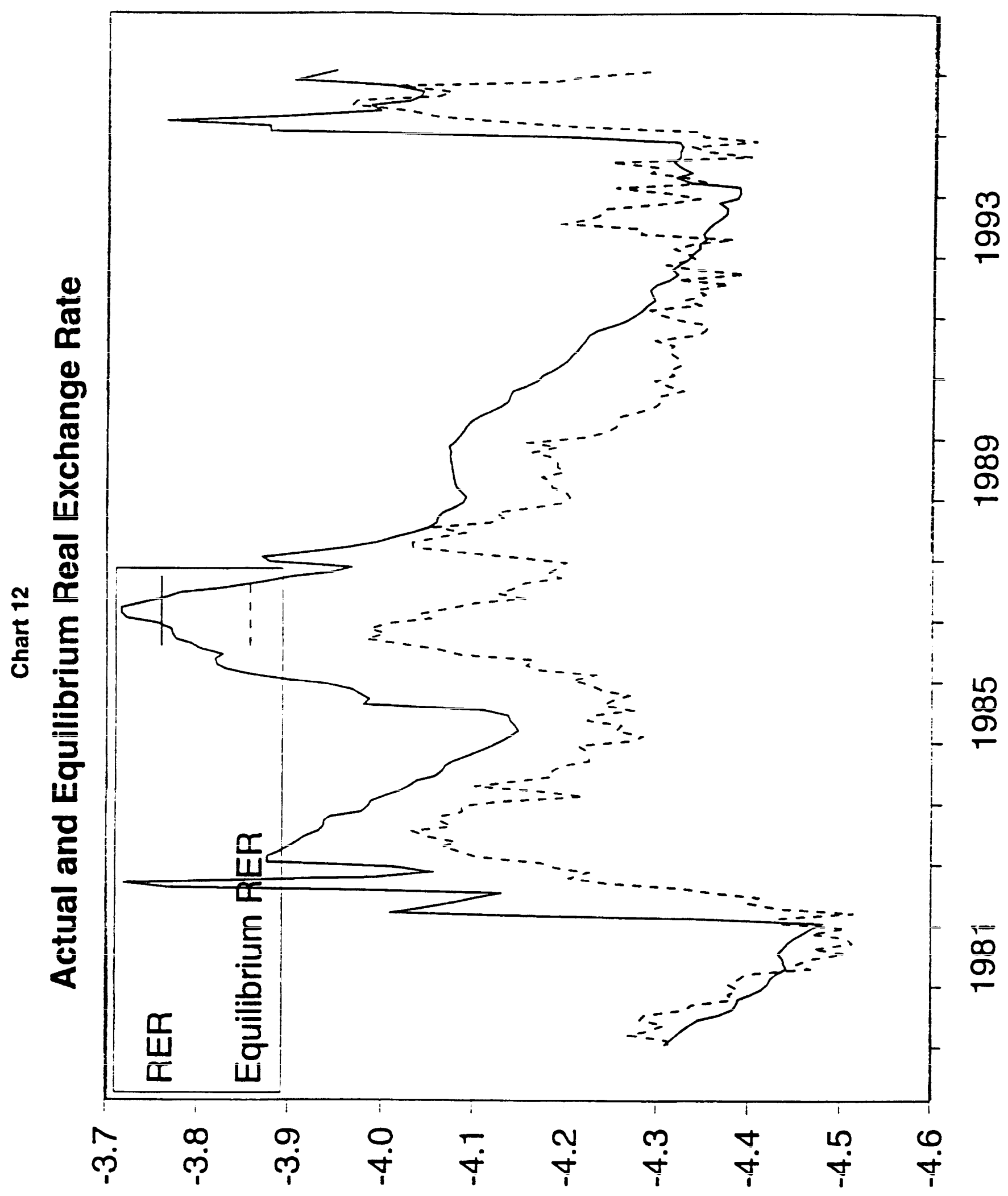



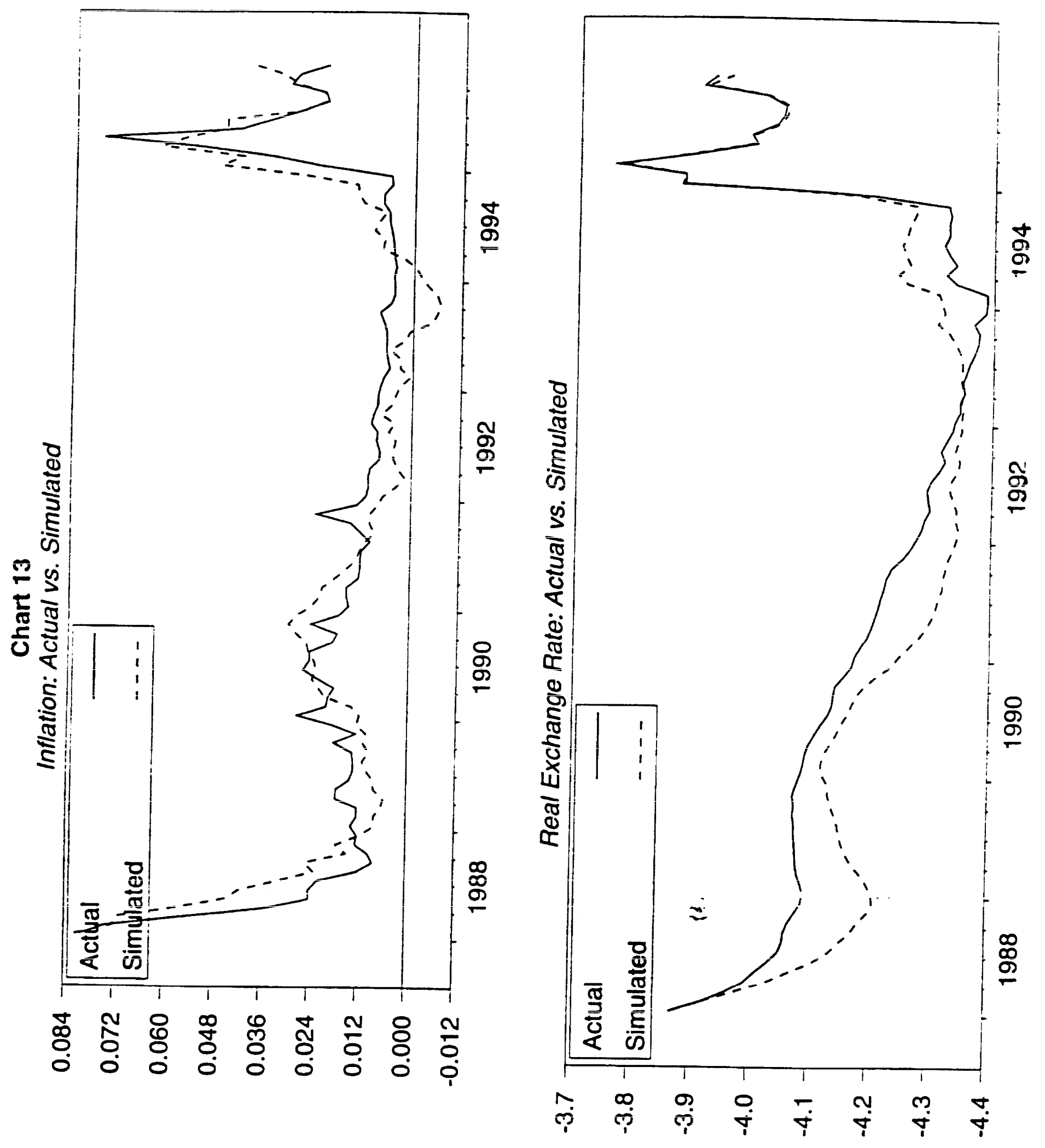


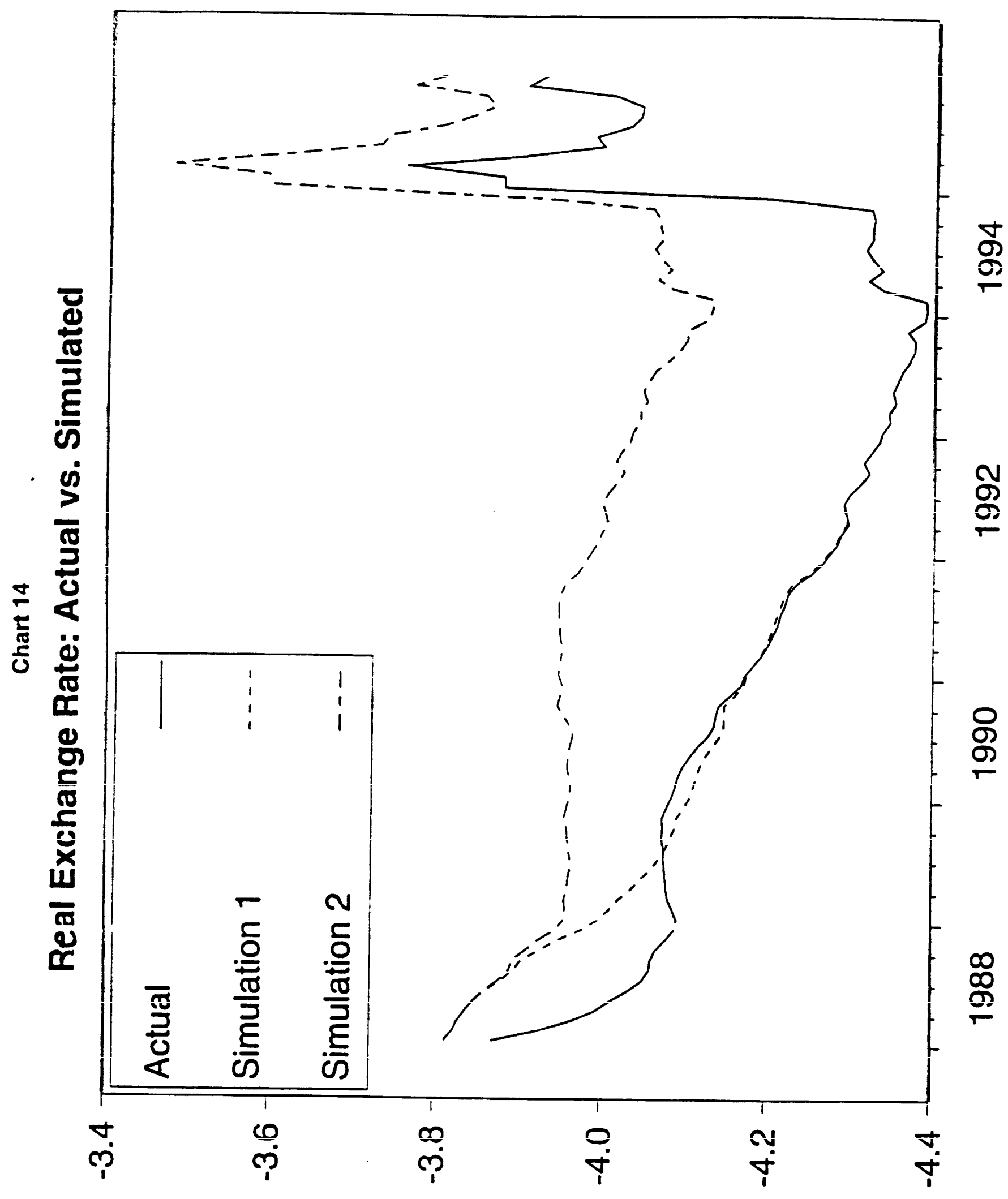


Chart 15. Exogenous Assumptions 1996-97
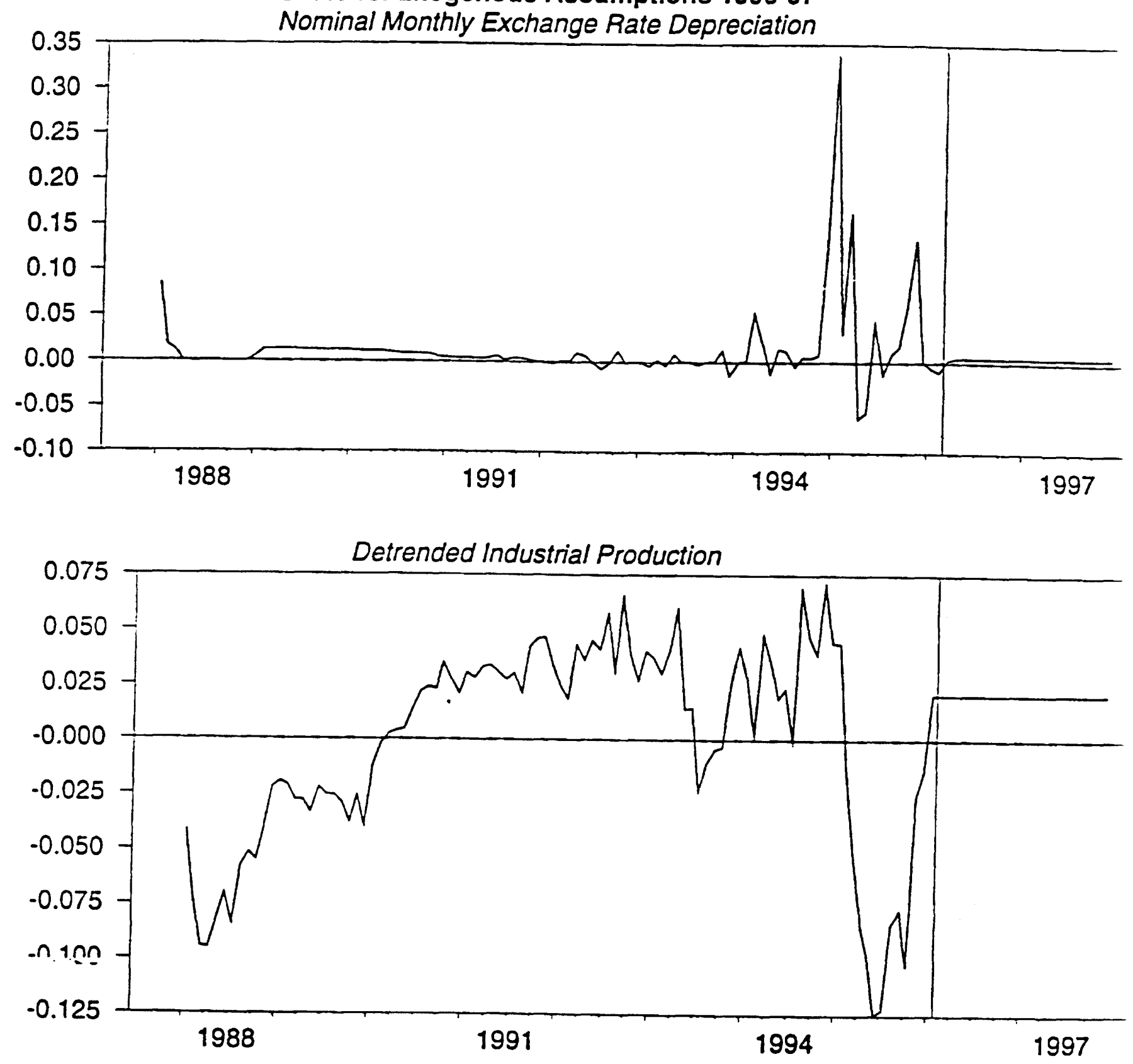

Notes: 1. Vertical line indicates stan of forecast values of series. 

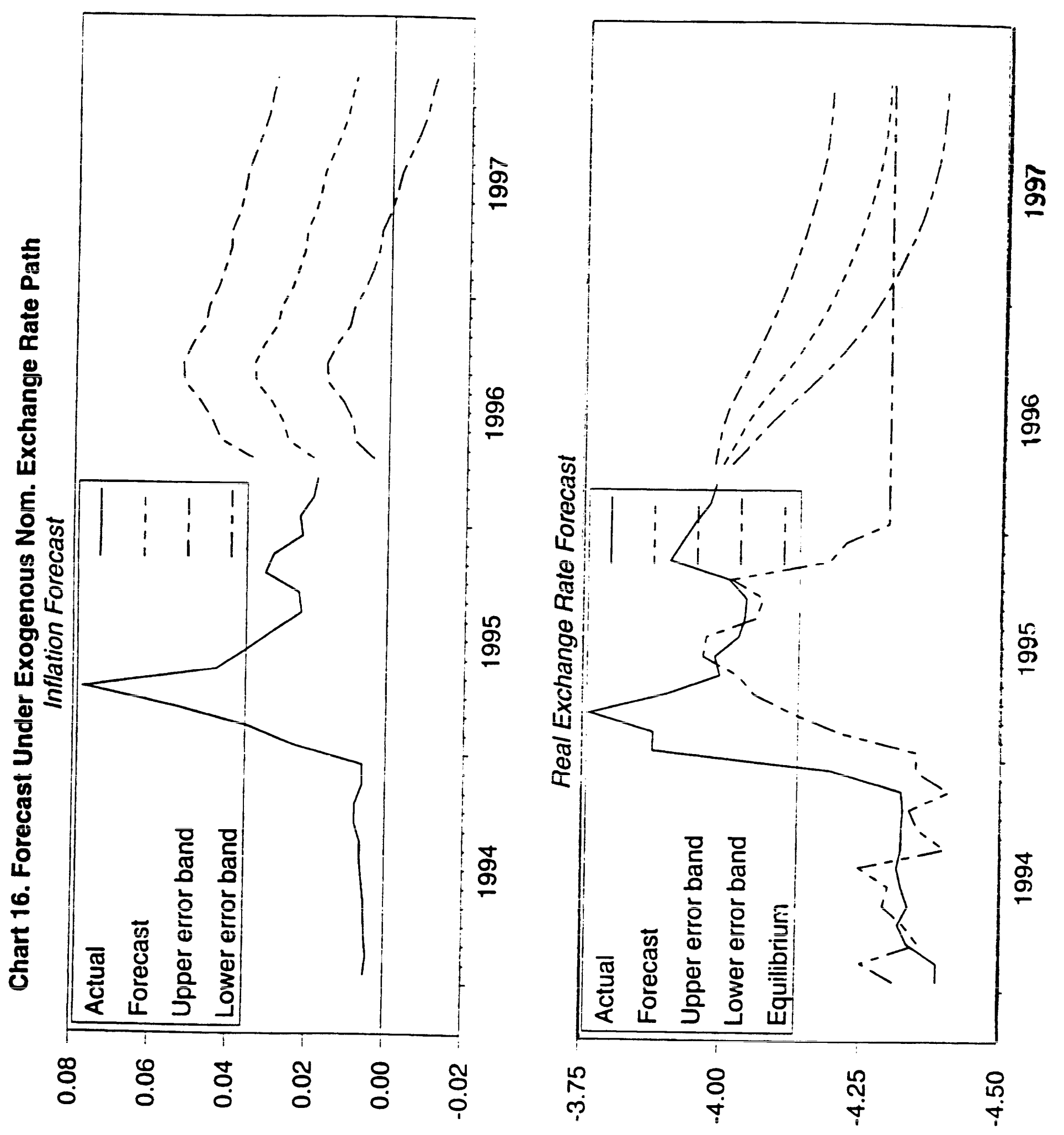


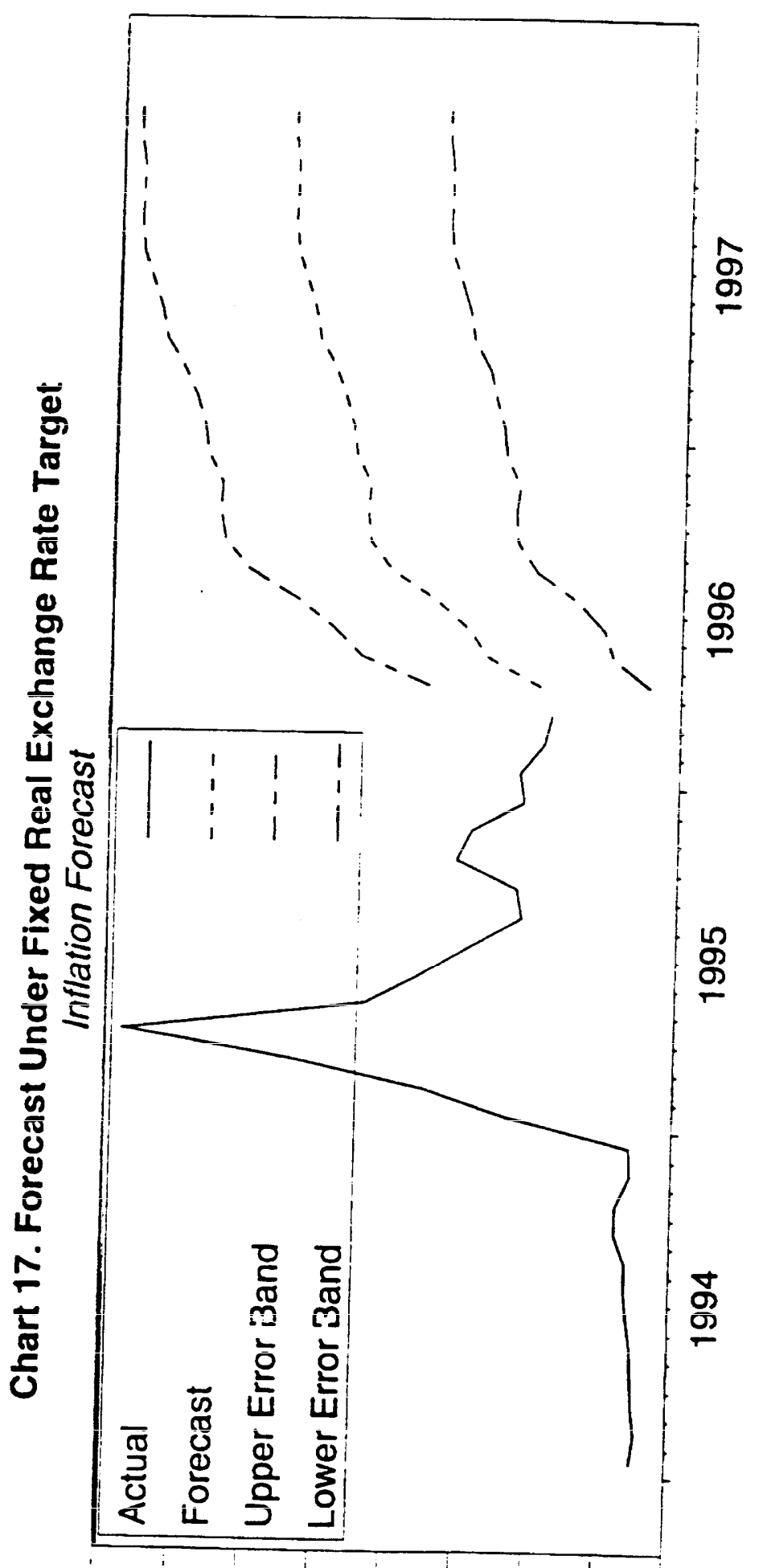

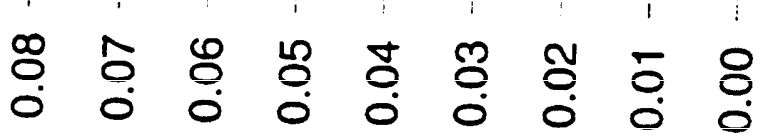

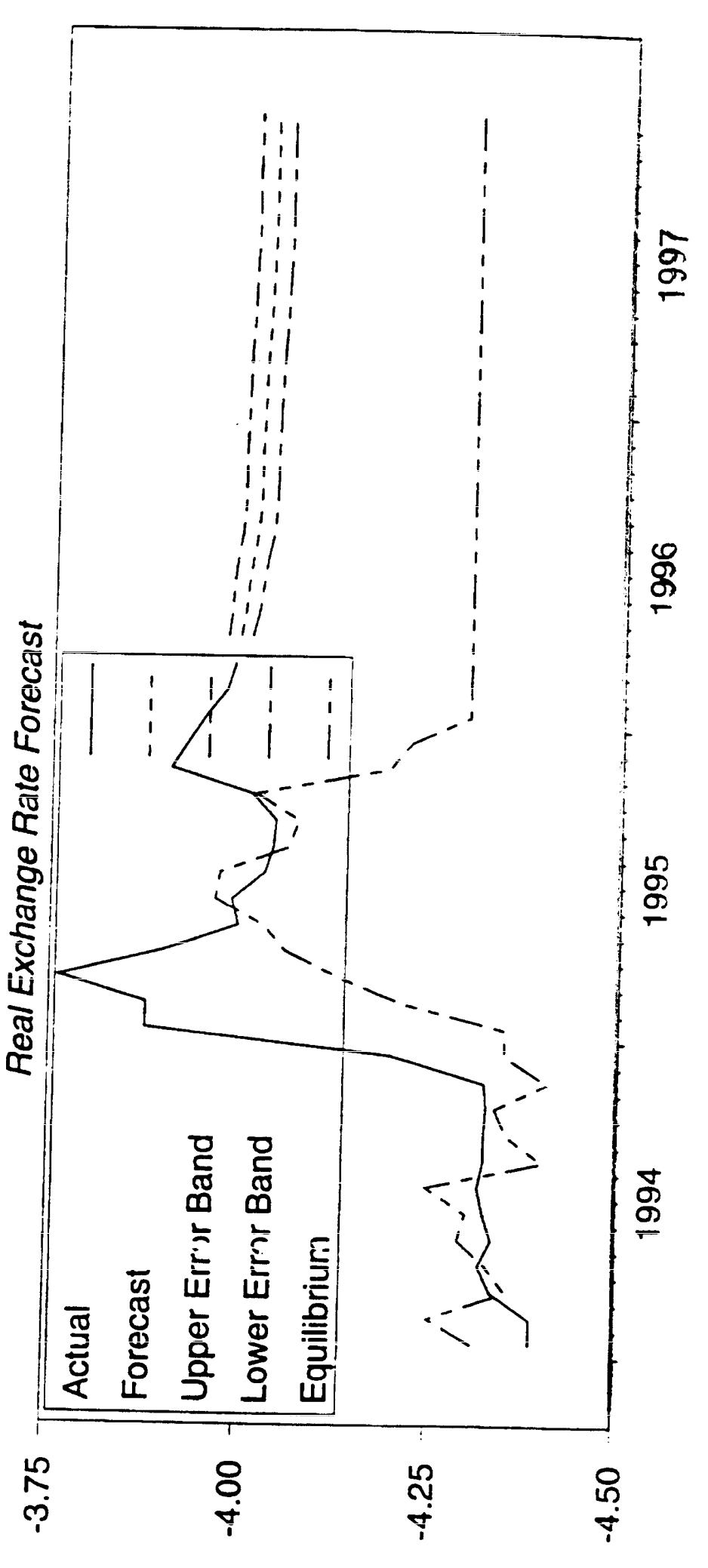




\section{International Finance Discussion Papers}

IFDP

Number

554

553

552

551

550

549

548

547

546

545

544

543

542
Titles

Author(s)

1996

Real Exchange Rates and Inflation in Exchange-Rate

Based Stabilizations: An Empirical Examination

Macroeconomic State Variables as Determinants

of Asset Price Covariances

The Tequila Effect: Theory and Evidence from

Argentina

The Accumulation of Human Capital: Alternative Methods and Why They Matter

Alternatives in Human Capital Accumulation:

Implications for Economic Growth

More Evidence on the Link between Bank

Health and Investment in Japan

The Syndrome of Exchange-Rate-Based

Stabilization and the Uncertain Duration of

Currency Pegs

German Unification: What Have We Learned from Multi-Country Models?

Returns to Scale in U.S. Production: Estimates and Implications

Mexico's Balance-of-Payments Crisis: A Chronicle of Death Foretold

The Twin Crises: The Causes of Banking and

Balance-of-Payments Problems

High Real Interest Rates in the Aftermath of

Disinflation: Is it a Lack of Credibility?

Precautionary Portfolio Behavior from a Life-Cycle Perspective
Steven B. Kamin

John Ammer

Martín Uribe

Murat F. Iyigun

Ann L. Owen

Murat F. Iyigun

Ann L. Owen

Michael S. Gibson

Enrique G. Mendoza

Martin Uribe

Joseph E. Gagnon

Paul R. Masson

Warwick J. McKibbin

Susanto Basu

John G. Fernald

Guillermo A. Calvo

Enrique G. Mendoza

Graciela L. Kaminsky

Carmen M. Reinhart

Graciela L. Kaminsky

Leonardo Leiderman

Carol C. Bertaut

Michael Haliassos

Please address requests for copies to International Finance Discussion Papers, Division of International Finance, Stop 24, Board of Governors of the Federal Reserve System,

Washington, D.C. 20551. 


\section{International Finance Discussion Papers}

IFDP

Number $\underline{\text { Titles }}$

Author(s)

1996

Using Options Prices to Infer PDF's for Asset Prices: An Application to Oil Prices During the Gulf Crisis

Monetary Policy in the End-Game to Exchange-Rate Based Stabilizations: The Case of Mexico

Comparing the Welfare Costs and the Initial Dynamics of Alternative Temporary Stabilization Policies

Long Memory in Inflation Expectations: Evidence from International Financial Markets

Using Measures of Expectations to Identify the Effects of a Monetary Policy Shock

Regime Switching in the Dynamic Relationship between the Federal Funds Rate and Innovations in Nonborrowed Reserves

The Risks and Implications of External Financial

Shocks: Lessons from Mexico

Currency Crashes in Emerging Markets: An

Empirical Treatment

Regional Patterns in the Law of One Price:

The Roles of Geography vs. Currencies

$\underline{1995}$

Aggregate Productivity and the Productivity

of Aggregates

A Century of Trade Elasticities for Canada, Japan, and the United States

Modelling Inflation in Australia

Hyperinflation and Stabilisation: Cagan

Revisited

On the Inverse of the Covariance Matrix in Portfolio Analysis
William R. Melick Charles P. Thomas

Steven B. Kamin John H. Rogers

Martin Uribe

Joseph E. Gagnon

Allan D. Brunner

Chan Huh

Edwin M. Truman

Jeffrey A. Frankel Andrew K. Rose

Charles Engel John H. Rogers

Susanto Basu John G. Fernald

Jaime Marquez

Gordon de Brouwer Neil R. Ericsson

Marcus Miller Lei Zhang

Guy V.G. Stevens 